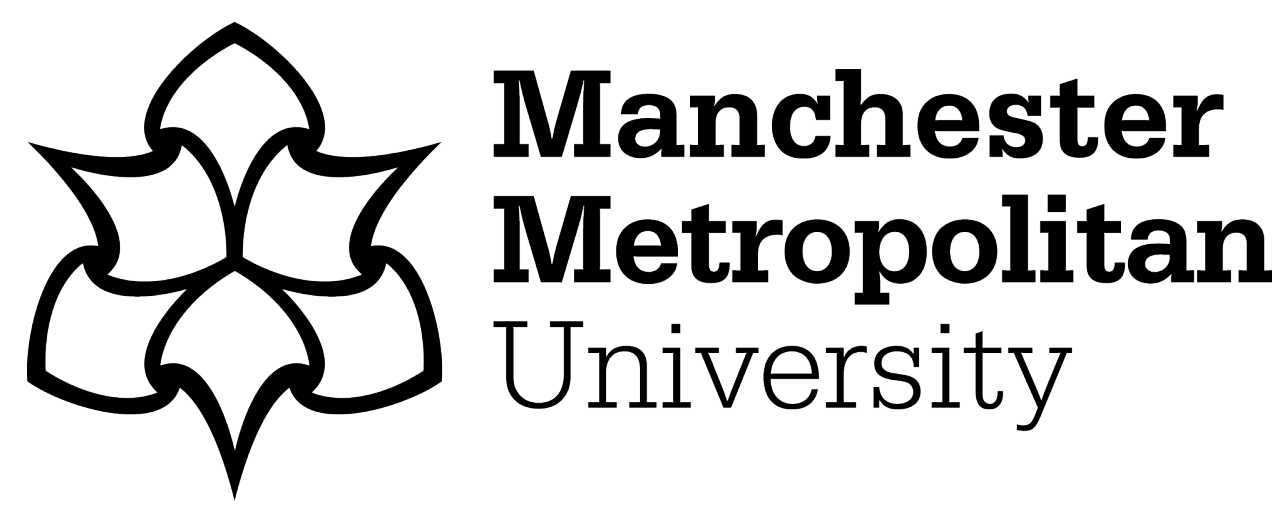

Amaibi, PM, Entwistle, JA, Kennedy, N, Cave, M, Kemp, SJ, PotgieterVermaak, S and Dean, JR (2019) Mineralogy, solid-phase fractionation and chemical extraction to assess the mobility and availability of arsenic in an urban environment. Applied Geochemistry, 100. pp. 244-257. ISSN 08832927

Downloaded from: https://e-space.mmu.ac.uk/622131/

Publisher: Elsevier

DOI: https://doi.org/10.1016/j.apgeochem.2018.12.004

Usage rights: Creative Commons: Attribution-Noncommercial-No Derivative Works 4.0

Please cite the published version 


\section{Mineralogy, solid-phase fractionation and chemical extraction to assess the mobility and availability of arsenic in an urban environment}

Patrick M. Amaibia, Jane A. Entwistle ${ }^{b}$, Nattalie Kennedyc, Mark Cave ${ }^{d}$, Simon J. Kemp ${ }^{d}$, Sanja Potgieter-Vermaak ${ }^{\mathrm{e}}$, John R. Dean ${ }^{\mathrm{a}^{*}}$

a Department of Applied Sciences, Northumbria University, Ellison Building, Newcastle Upon Tyne, NE1 8ST, UK.

b Department of Geography and Environmental Sciences, Northumbria University, Ellison Building, Newcastle Upon Tyne, NE1 8ST, UK.

c Department of Environmental Protection, St. Helens Council, $3^{\text {rd }}$ Floor, Wesley House, Merseyside, WA10 1HE, UK

d British Geological Survey, Environment Science Centre, Keyworth, Nottingham, NG12 5GG, UK

e School of Science and the Environment, John Dalton Building, Manchester Metropolitan University, M1 5GD, UK

* Corresponding author: John R Dean, Department of Applied Sciences, Northumbria University, Ellison Building, Newcastle Upon Tyne, NE1 8ST, UK. Email:

John.Dean@northumbria.ac.uk

\section{Abstract}

A multi-disciplinary approach, using chemical extraction and analytical structural techniques, has been used to assess the mobility and availability of arsenic in urban soil samples from two current housing sites. Arsenic concentrations in each site varied between $126-1,660$ $\mathrm{mg} / \mathrm{kg}$ (Site A) and $40-24,900 \mathrm{mg} / \mathrm{kg}$ (Site B). Using a non-specific sequential extraction approach, it was possible to identify two distinct, site specific, As-containing fractions i.e. FeAs-Ca (Site A) and As-Fe (Site B), in the soils. Further investigation using a sequential extraction approach identified the main As component in the reducible fraction, linking As with Fe-oxides in the soils. Further investigation of the crystalline mineral phases, by X-ray 
diffraction, within the most As-contaminated soils (up to $24,000 \mathrm{mg} / \mathrm{kg}$ ) identified no Asbearing minerals but identified the major component as quartz $\left(\mathrm{SiO}_{2}\right)$ with an array of minor and trace minerals. Further mineralogical investigation, using micro-Raman in the major Ascontaminated soils (from Site B) as well as re-confirming the presence of the major mineral (quartz) additionally identified the As-bearing minerals pharmacosiderite $\left(\mathrm{KFe}_{4}\left[\left(\mathrm{H}_{2} \mathrm{O}\right)_{4}\left(\mathrm{AsO}_{4}\right)_{3}\right] \cdot 6 \mathrm{H}_{2} \mathrm{O}\right)$ and mimetite $\left(\mathrm{Pb}_{5}\left(\mathrm{AsO}_{4}\right)_{3} \mathrm{Cl}\right)$ in the trace mineral component, alongside amorphous carbon, chromite $\left(\mathrm{FeCr}_{2} \mathrm{O}_{4}\right)$, goethite $(\alpha-\mathrm{FeO}(\mathrm{OH}))$, gypsum $\left(\mathrm{CaSO}_{4} . \mathrm{H}_{2} \mathrm{O}\right)$, muscovite $\left(\mathrm{KAl}_{2}\left(\mathrm{AlSi}_{3} \mathrm{O}_{10}\right)(\mathrm{F}, \mathrm{OH})_{2}\right)$, magnetite $\left(\mathrm{Fe}_{3} \mathrm{O}_{4}\right)$, martite $\left(\alpha-\mathrm{Fe}_{2} \mathrm{O}_{3}\right)$, psilomelane $\left.\left(\mathrm{Ba}, \mathrm{H}_{2} \mathrm{O}\right)_{2} \mathrm{Mn}_{5} \mathrm{O}_{10}\right)$, pyrrhotite $\left(\mathrm{Fe}_{7} \mathrm{~S}_{8}\right)$ and rutile $\left(\mathrm{TiO}_{2}\right)$. The identification and presence of several Fe-rich minerals could be considered as the major hosts of As in the soil matrix. It is concluded that while the soil contains elevated levels of As, it's lack of mobility in the soil, means that minimal remedial action is required provided the sites are left undisturbed and free of human endeavour and activity.

Keywords: arsenic; urban soils; sequential extraction; mineralogy; risk assessment.

\section{Introduction}

Mobility of potentially harmful elements (PHEs) in the environment can have a significant impact on human health. Often, the presence of PHEs can result from the natural weathering and erosion of the underlying geology (WHO, 2001). However, and in addition, anthropogenic activity from former historical industrial sources can contribute to the enrichment of PHEs. The presence and elevated concentration of PHEs become more significant if the PHE is mobile in the environment. The main risks from PHEs are normally because of ingestion, inhalation or dermal contact with hand-to-mouth contact from soil as a major factor. Soil contamination is a major environmental threat to human health in many parts of the world. Arsenic contamination probably poses the greatest significant health risk because of its 
presence in the terrestrial and aqueous environment. Several cases have been reported in different regions of the world, most significantly around West Bengal (India), Bangladesh, Chile, Taiwan, Nepal and Vietnam, where many of the population have suffered from chronic diseases by drinking As-contaminated water (Smedley and Kinniburgh, 2002; Da Sacco et al. 2013; Chen et al. 2013). Long-term human exposure to As can cause cancer of the skin, lungs, liver, bladder, and other effects such as hematopoietic depression and weight loss (ATSDR, 2009; IARC, 2004). The maximum permissible arsenic concentration in drinking water is $0.01 \mathrm{mg} / \mathrm{L}$, and concentrations above this can increase the risk of cancer (ATSDR, 2007; WHO, 2001). Arsenic is a naturally occurring element found in the environment. The range at which As exists in soil varies normally between 0.2 and $40 \mathrm{mg} / \mathrm{kg}$ (Fitz and Wenzel, 2002; Kabata-Pendias, 2010; Mandal and Suzuki, 2002). It is a toxic element at high concentration and can become easily mobile due to changes in environmental conditions. The distribution of As into the environment occurs through weathering and anthropogenic actions including mining, urban waste, cattle farming and industrial activities (Popovic et al. 2001). Of all the solid mineral phases, including the carbonates and silicates present in soil, the Fe-oxyhydroxides can easily bind to As at a pH $<7.8$ (Yang et al. 2002). However, there may be a gradual change over a long period, where the As is incorporated and closely fixed to Fe-oxyhydroxides mineral structure by forming an inner or outer-sphere complex compound. This transformation is likely to occur due to soil ageing (Palumbo-Roe et al. 2015; Fendorf et al. 2004).

The amount of contaminant present in the soil may be an indicator of risks to human and environmental health. In practice, in the UK the non-statutory Contaminated Land Exposure Assessment framework (CLEA) provides a standard approach in dealing with land contamination that may pose a potential risk to human health (DEFRA and Environment Agency, 2002). Since 2012, a new system has been used to assess the human health risk 
from contaminants. This four category system ranges from Category 4 , which is a level of low risk that the land can pose to human health, through to Category 1 , where a significant possibility of significant harm (SPOSH) is high (CL:AIRE, 2014). A staged or 'tiered' approach is recommended in assessing the risks from contaminated land in the UK. The three stages of risk assessment include Preliminary Risk Assessment (PRA), Generic Quantitative Risk Assessment (GQRA) and Detailed Quantitative Risk Assessment (DQRA). The PRA involves gathering of information about the site under investigation (CL:AIRE, 2014). The application of a category 4 screening level (C4SL) is part of the GQRA process and the DQRA may be required where the soil concentrations exceed the critical concentration for the contaminants of concern. The C4SL is derived from health based guidance value (HBCV) at low level of toxicological concern (LLTC) using the modified CLEA model (CL:AIRE, 2014). Two C4SLs for residential land-use have been developed for As; they are 37 and $40 \mathrm{mg} / \mathrm{kg}$ for As in a residential area with and without home-grown produce, respectively.

Human exposure to soil contaminants can occur via oral ingestion, inhalation or dermal contact, relating to routes in which contaminants enter the human body (i.e. the mouth, nose and skin, respectively). For ethical and technical reasons, it is not easy to measure directly the contaminants in human or animal surrogates. Several methods have been developed for in vitro bioaccessibility testing to provide a conservative estimate of bioavailability by the ingestion route (Denys et al. 2012; Basta et al. 2007; Juhasz et al. 2007). These methods include Physiologically Based Extraction Test (PBET) (Ruby et al. 1993; Kim et al. 2002), the Solubility Bioaccessibility Research Consortium (SRRC) assay (Drexler, 1999; Kelley et al. 2002), in vitro gastrointestinal extraction method (Rodriguez et al. 1999; Schroder et al. 2003), the German standard bioaccessibility methodology (DIN) (DIN, 2000; Hack and Selenka, 1996) and the Unified BARGE Method (UBM) (Wragg et al. 2011). These methods 
mimic the human physiological conditions based on the ability that it can predict bioavailability compared with animal model (Juhasz et al. 2014). Bioaccessible contaminant fractions in soil may not completely interpret mobility of the contaminant without considering the soil properties such as soil pH, soil organic matter (SOM), soil texture and the solid mineral phases (i.e. carbonates, aluminosilicates and Fe/Mn oxides) as part of the factors controlling bioaccessibility. Mineralogical forms of PHEs, especially $\mathrm{As}$ and $\mathrm{Pb}$, are important factors that relate to the bioaccessibility of the elements. For example, Wragg et al. 2007, concluded that the dominant mechanism controlling As bioaccessibility is the release from Fe-oxides. Trace elements in soil are mainly adsorbed or fixed to the crystal structures of the solid mineral phases. For example, Fe-oxides have been found to be a major host to As present in soils, where the forms of As are adsorbed on the charged surface of the Fe-oxides phase (Smedley and Kinnniburgh, 2002).

The chemical constituents of soil control the mobility and bioavailability of trace elements that can be distributed in the environment. A selective sequential chemical extraction can be employed to investigate the distribution of trace elements amongst solid phases. The Community Bureau of Reference (BCR) developed a harmonized, three-stage, sequential extraction scheme (SES) that was subsequently updated and modified (Rauret et al. 1999). The three-stage BCR-SES incorporates extraction with $0.11 \mathrm{~mol} \mathrm{~L}^{-1}$ acetic acid (stage 1); Stage 1 (Exchangeable, water- and acid-soluble fraction) nominally targets the soluble and exchangeable cations and carbonates. Stage 2 (the reducible fraction) nominally targets the Fe-Mn oxyhydroxides using $0.5 \mathrm{~mol} \mathrm{~L}^{-1}$ hydroxylamine hydrochloride at $\mathrm{pH} 1.5$, while Stage 3 (the oxidisable fraction) targets the organic matter and sulphides using hydrogen peroxide at $85^{\circ} \mathrm{C}$, followed by $1.0 \mathrm{~mol} \mathrm{~L}-1$ ammonium acetate. A recommended Stage 4 is often included to determine the residual fraction, and allow a mass balance for the SES; this is done using 
aqua regia. The sum of the four stages can then be compared to a separate aqua regia digest of the soil sample.

Traditional sequential extraction methods are operationally defined to select targeted solid phases in the soil matrix. This has sometimes led to a failure to extract the targeted phases of interest due to a lack of specificity by the extraction medium (Rao et al. 2008; Filgueiras et al. 2002). However, Rodriguez et al. 2003 identified a link between chemical extractions and bioavailable As from contaminated soils. Subsequent interpretation found a strong relationship between the bioavailable As and the hydroxylamine hydrochloride extractant (used as part of the sequential extraction method). Similarly, Palumbo-Roe et al. 2015 were able to link As bioaccessibility and As extracted by hydroxylamine hydrochloride. The use of hydroxylamine hydrochloride, in each case (Rodriguez et al. 2003; Palumbo-Roe et al. 2015), being selected to target the dissolution of amorphous Fe oxyhydroxides.

An alternate approach to sequential extraction methods is the use of non-specific extractions linked to chemometric data processing to identify the solid phase extraction of PHEs. To investigate the large volume of data that the extractions generate multivariate statistics are applied to link relationships that exist within groups (Cave et al. 2004). The approach, the Chemometric Identification of Substrates and Element Distributions (CISED), has been modified in terms of the original extractants proposed and applied to certified reference material (SRM 2710) (Wragg and Cave 2012). Despite the importance of the sequential extraction methods in determining the distribution of trace elements among solid phases, few researchers have studied chemical forms of As using CISED and BCR-SES methods. However, none of the traditional methods has adopted non-specific chemical reagents to release As from the soil matrix followed by a chemometric data analysis of the soil extract. It is important to compare the methods to provide a better understanding on the mobility and chemical forms of As in soils. Since As bioaccessibilty is controlled by several soil 
parameters such as $\mathrm{pH}$, mineralogy, particle size fraction and chemical speciation (Cave et al. 2011; Ruby et al. 1996), it is important to gather information about the mineralogy of the chemical elements relating to a site to support both oral bioaccessibility testing and the mobility and distribution of As in the soil. The key factor that may control the bioaccessibility is the mineralogy of the element. This is a combination of the original mineralogy of the parent soil material and the secondary minerals caused by weathering (Swartjes, 2011). This research paper is focused on the assessment of the mobility of arsenic from two, historic industrial sites, which have been part of two distinct housing estates for more than 65 years. Knowledge of the mineralogy of the soil samples from the affected sites can provide specific knowledge on the mobility of arsenic.

The aims of this paper are focused on the analysis of As in the soil from two urban residential sites. Two sequential extraction methods have been used to identify the geochemical distinct forms of As in the soils, using a non-specific sequential extraction method (CISED), and to assess the mobility of As, using the BCR sequential extraction scheme. Subsequently, to use analytical structural elucidation techniques, namely X-ray Diffraction, Micro-Raman spectroscopy and individual particle analysis SEM-EDX to confirm the presence of As in distinct mineral forms. Finally, to conclude on the overall mobility of As in the soils from the two residential urban sites and suggest appropriate remedial action.

\section{Experimental}

\section{Site description and sampling}

Two current urban residential housing sites were selected for investigation. Both sites had an industrial past: Site A was a former industrial site for an alkali works that operated between 1849 and 1928 whereas Site B was a former industrial site for a glass and chemical works that operated between 1840 and 1890 . Both sites were re-developed as residential housing estates in the 1950s. Soil samples (70) were collected from across the sites using a hand- 
held auger. Sampling equipment was cleaned with acetone after each sample was collected and samples were handled with one-use nitrile rubber gloves to avoid cross contamination. Most samples were collected from the topsoil (uppermost $0.2 \mathrm{~m}$ depth) (Table 1), which was the material residents are more likely to have regular contact with. Sampling was carried out on both front and rear gardens; in each case the rear garden was much larger, typically double the area, with cultivated areas occasionally used by the residents to grow vegetable produce. Samples were collected from the cultivated areas to avoid hardstanding landscaped areas. The samples were stored in self-sealing Kraft (Geology superstore, UK) bags after drying; samples were dried inside a drying cabinet at a temperature $<40{ }^{\circ} \mathrm{C}$ for 4 days, then disaggregated and sieved into smaller particle fractions following the standard procedures described by British Standard BS 933-1 (BSI, 1997; Cave et al. 2003). Samples were gently disaggregated with a mortar and pestle to break down the soil particles before sieving. The soil samples were passed through a $<2 \mathrm{~mm}$ nylon sieve removing all extraneous materials including stones, bricks and other debris. The $<2 \mathrm{~mm}$ fraction was subsequently split and then screened through a $250 \mu \mathrm{m}$ sieve.

\section{Chemicals/reagents}

All chemicals used were certified analytical grade. All solutions and dilutions were prepared using ultra-pure water from a Milli-Q purifier system with a water resistivity $>18.2{\mathrm{M} \Omega \mathrm{cm}^{-1}}^{-1}$ $27^{\circ} \mathrm{C}\left(\mathrm{Q}^{\mathrm{TM}}\right.$ Millipore, Molsheim, France). A multi-element calibration solution (100 mg/L) containing 26 elements (Ag, Al, As, Ba, Be, Ca, Cd, Co, Cr, Cu, Fe, K, Mg, Mn, Mo, Na, Ni, $\mathrm{Pb}, \mathrm{Sb}, \mathrm{Se}, \mathrm{Sn}, \mathrm{Sr}, \mathrm{Ti}, \mathrm{TI}, \mathrm{V}$ and $\mathrm{Zn}$ ) was supplied by SPEXCertiPrep (Middlesex, UK). In addition, single elemental standards (1000 mg/L) of $\mathrm{Li}, \mathrm{P}, \mathrm{S}$ and Si were obtained from SPEX Certiprep (Middlesex, UK), Merck Supplies (Lutterworth, UK), MBH Analytical Ltd, (Barnet, UK) and ROMIL Ltd, (Cambridge, UK), respectively. A single elemental standard solution of 
Scandium (1000 $\mu \mathrm{g} / \mathrm{mL})$, used as an internal standard, was obtained from LGC standards (Middlesex, UK). Certified reference materials (BCR 701, SRM 2710a, CRM059-50) used for instrument calibration and quality control were also obtained from LGC standards (Middlesex, UK).

\section{Instrumentation}

Further experimental details are shown in the Supplementary Information.

Multi-element analysis of sample extracts was done using an inductively coupled plasma atomic emission spectrometer (ICP-AES) (PerkinEImer Optima-8000, Beaconsfield, UK) with automated computer-controlled WinLab32 software. Typical operating conditions were: RF power $1.3 \mathrm{~kW} @ 40 \mathrm{MHz}$; Outer gas flow rate of $15 \mathrm{~L} / \mathrm{min}$ Ar; auxiliary gas flow rate of 0.2 $\mathrm{L} / \mathrm{min} \mathrm{Ar}$; and, nebulizer flow rate of $0.55 \mathrm{~L} / \mathrm{min} \mathrm{Ar}$.

X-ray diffraction (XRD) analysis was done using a PANanalytical X'Pert Pro series diffractometer fitted with a cobalt-target tube, X'Celerator detector and operated at $45 \mathrm{kV}$ and $40 \mathrm{~mA}$. Samples were selected based on the elevated As concentrations in order to identify the As-bearing minerals present in the soils.

Micro-Raman spectrometry analysis was done on sub-samples of $<250 \mu \mathrm{m}$ fraction using a Renishaw InVia Raman microscope fitted with a Peltier-cooled charge-coupled device detector. The source of excitement was a $514.5 \mathrm{~nm} \mathrm{Ar}{ }^{+}$laser. The instrument was calibrated at the beginning of each set of analysis using a silicon chip. For each analysis, a peak was achieved at $520.5 \pm 0.05 \mathrm{~cm}^{-1}$ (for Si as a reference point) with an intensity to monitor the instrument performance. In general, the instrument was operated in static mode (limiting the spectral range to about 800 wavenumbers) and the number of acquisitions varied between 
$30-1001$-second exposures to ensure an acceptable S/N ratio. The power density varied between $2-8 \mathrm{~mW}$ at the sample.

Individual particle analysis using a scanning electron microscope (FEI Quanta 200, UK) equipped with energy dispersive X-ray spectrometry (SEM-EDX). The instrument was set at low vacuum (tungsten filament electron source) and switched to backscatter electron microscope (BSEM) solid state detector used for a non-conductive material. BSEM observations were made using a $\mathrm{Si}(\mathrm{Li})$ detector, specified energy resolution at $5.9 \mathrm{keV} ; 133$ $\mathrm{eV}$. For a better resolution, the stage was adjusted to $10 \mathrm{~mm}$ working distance at $20 \mathrm{kV}$ accelerating voltage with a low magnification to allow a small spot of the image to appear as the particle at a given spot. This was equipped with a digital energy-dispersive X-ray microanalysis system (Oxford Instruments INCA X-sight LN2 EDS, UK).

\section{Extraction Procedures}

\section{Microwave-assisted acid digestion}

Microwave-assisted acid digestion, followed by ICP-AES analysis, was used to determine the pseudo-total element concentrations in soil extracts. To determine the pseudo-total element concentrations, soil samples were treated with aqua regia $\left(\mathrm{HCl}: \mathrm{HNO}_{3}\right.$ in a ratio of $\left.3: 1 \mathrm{v} / \mathrm{v}\right)$. The microwave-assisted digestion was achieved using a closed vessel microwave accelerated reaction system (MARS 5, CEM Corporation). This instrument was set at a power of 440 Watts for 40 min with a cooling time of $20 \mathrm{~min}$. The maximum pressure and temperature allowed for the XP-1500 vessel ranged from $100-600$ psi and $240-300^{\circ} \mathrm{C}$, respectively. 


\section{Non-specific sequential extraction}

A non-specific extraction method developed by Cave et al. (2004) was applied to assess the partitioning of trace metals among the solid mineral phases; the Chemometric Identification of Substrates and Element Distributions (CISED). The multi-element data were processed using the self-modelling mixture resolution (SMMR) algorithm described in previous studies (Cave et al. 2004; Wragg and Cave, 2012). A series of files including the extraction profile outputs, the elemental composition data for each of the test soils and the distribution of elements amongst the components were produced. These datasets were refined to reproduce the modified extraction profiles for each of the test soils. The modified extraction profile can be used as a chemical signature to identify the relative solubility of the components based on their distinct chemical properties. The results of the test soils were evaluated based on a CISED test of certified soil reference material (SRM 2710a); an earlier version of this same certified reference material (SRM 2710) has been analysed previously by Cave et al. (2004).

\section{BCR-SES extraction}

Trace metals associated with different mineral phases in soil can be fractionated by sequential extraction methods (Rao et al. 2008; Sahuquillo et al. 2003; Filgueras et al. 2002; Bacon and Davidson 2008). A sequential extraction approach originally developed by the Community Bureau of Reference (BCR), but later modified, was adopted due to the sensitivity of As to changes in $\mathrm{pH}$ and redox conditions in soil (Rauret et al. 1999). A certified reference material (BCR 701) was applied to evaluate the method.

For further experimental details see the Supplementary Information.

\section{Quality assurance/quality control}

Quality control procedures were put in place to ensure accurate and precise measurement of results for all the experiments. The instruments were calibrated with standard solutions and 
reference materials to validate the analytical methods. In the case of ICP-AES analysis, the analytical error was between 2 - $5 \%$ relative standard deviation (RSD) with an internal standard recovery of $80-120 \%$. To avoid matrix interference, an internal standard was used for the samples, calibration standards and blank preparation. For each element, a suitable wavelength was selected to verify the presence of that element in a certified reference material prior to sample analysis using the ICP-AES. The limit of detection (LOD) was determined using three times the average standard deviation, while the limit of quantification (LOQ) was derived using ten times the average standard deviation from the method blanks for 23 elements (Table S1).

\section{Results and Discussion}

\section{Non-specific sequential extraction using CISED}

A multi-step sequential extraction method, developed by Cave et al. (2004), was employed to identify geochemically distinct components soluble in aqua regia and assess the distribution of As amongst the components in the 22 urban soils and a certified reference soil (SRM 2710a). Subsequently, the multi-element extract data (Table S2), based on the analysis of 23 elements in 14 extraction steps (E1 - E14) in order of increasing acid strength, were subject to a chemometric data processing method (Cave et al. 2004; Wragg and Cave, 2012; Appleton et al. 2012), using SMMR.

Initially, an attempt was made to compare and evaluate the CISED extraction procedure using a certified reference material (SRM 2710a, a soil from Montana, USA) to predict the number of extractable physicochemical components and their chemical compositions. Figure 1 shows the MATLAB predictive modelling output for identifying the number of components. The SMMR model generated four graphical outputs to predict the number of extracted physicochemical components. Each graphical plot suggests a criterion that selects the best 
fitted model for identifying the number of components from different statistical models (Cave et al. 2004). In the topmost plot (Figure 1a), the goodness of fit of the model was determined by the method of the maximum likelihood factor analysis. The second plot (Figure 1b) estimated the number of components based on the average absolute differences between the modelled and actual data with a minimum potential bias. While, the third plot (Figure 1c) contained information on the best fit of the test data using the Bayesian procedure (BIC) as statistical model identification. The final plot (Figure 1d) was derived from the Akaike information criterion or minimum theoretical information criterion (AICc) to estimate the number of components. Of all the four plots, the AICc model with the lowest fit value was chosen as optimum. The AICc is closely linked with all other plots used in estimating the number of predicted components. From the SMMR predictive modelling, the estimated number of the components is 8 as observed by the minimum values. Table S3 shows the number of identified components in SRM 2710a when compared with previously reported studies of SRM 2710. It was observed that the number of identified components ranged from 7 - 12. Different extraction solutions were applied to the reference material SRM 2710(a) (Table S3). The number of elements analysed also varied from 19 to 23 . The number of components in SRM 2710a observed in this study differs from that previously found for SRM 2710 by Cave et al. (2004). Although, the SRM 2710 a soil was collected from a site close to that originally used for SRM 2710, this sample (SRM 2710) was no longer available due to remediation of the area. A nearby site within the same location (floodplain of the Silver Bow Creek) was selected for sampling of SRM 2710a. This site is approximately five miles from the original location used for SRM 2710. It is expected that there could be close similarity in terms of the geology of the area. However, the number of extracted physicochemical components differs from one study to another due to the different mineral acids used for the extraction of the soil and the number of elements analysed. In the original methodology, it 
was noted that using $\mathrm{HNO}_{3}$ alone is unsuitable as an extraction reagent, and results in poor extraction of Fe-oxides from the soil (Cave et al. 2004). When aqua regia was used, the extraction of Fe (possibly Fe-oxides) and Ni was found to improve significantly (Cave et al. 2004). The addition of $\mathrm{H}_{2} \mathrm{O}_{2}$ along with varying concentrations of aqua regia can dissolve the organic matter and prevents further precipitates. The improved CISED methodology was developed by Wragg and Cave (2012) using three different extractants $\left(\mathrm{HNO}_{3} ; \mathrm{HNO}_{3}\right.$ followed by $\mathrm{HCl}$, and aqua regia) and the extracts were analysed for 23 elements per sample. Using the aqua regia extractant has improved the extraction of different components. By default, the modified SMMR model requires a full suite of analytes (23 elements) comprising major and trace elements. The number of analysed elements may possibly contribute to the difference in the number of components obtained in each reference material. In a separate SMMR model output, the extraction profile of all the components were shown along with the composition of the components. Table S4 shows the summary of the tentative geochemical assignment of the identified components compared with a previous study (Cave et al., 2015). In the present study, 8 components were identified in SRM 2701a, while the previous study has identified 7 components in SRM 2710 by the SMMR model. The components were tentatively assigned to the major solid phases such as exchangeable, Fe-oxides, carbonate and pore-water salt found in soils.

\section{Solid-phase partitioning of As}

The ability of the chemometric approach to identify the physicochemical components in the 22 test soils was evaluated with 14 extracts per soil followed by ICP-AES, of 23 elements. The CISED data for the soil extracts used for the SMMR process are in Table S5. Figure 2 shows the number of physicochemical components identified by the SMMR modelling technique. The soil extracts for each of the study sites were processed as a group, and then 
combined into a single input data for the SMMR analysis. The SMMR modelling clearly identified 16 distinct physicochemical components for each site (Figure 2). The minimum value for the Akaike information criterion (AIC) closely linked to the Bayesian information criterion (BIC) was chosen as the best fit model. A total of 16 physicochemical components were identified in each site, which suggests that the sites may be geochemically similar. The amount of extractable As associated with the 16 physicochemical components are presented in Table 2. The SMMR model revealed how the total As soil contents were distributed among the various components. The components (Figure S1) were tentatively assigned into different solid phases (Table 2). The geochemically assigned solid phases highlighted the distribution of As, with varying amounts in each component. The results indicate no adsorbed As on carbonate, aluminosilicate and Mn-oxide phases in the soil; just the presence of As in an arsenate phase. The majority of As soil content is bound to Fe-oxides phases. It is released only as the Fe-oxides are dissolved at high acid concentration (Cornell and Schwertmann, 1996; Smedley and Kinniburgh, 2002; Figueiras et al. 2002).

Figure 3 shows the total extractable As distributed among the components. The distribution of the total extractable As among the identified components in both sites is similar. The highest extractable As was obtained in the Fe-As-Ca and As-Fe components from Site A and Site $B$, respectively. For each of the sites, the chemical composition of the As containing components varies suggesting that the soil matrix may contain two different forms of arsenate. Due to the past industrial activities, the two study sites contain As-enriched soils that account for the different As-containing components. A plot of the component distribution, for both sites, was also done (Figure 4). It is noted that for both Site A, the Fe-As-Ca component, and Site B, the As-Fe are only extracted, almost exclusively, when the higher acid concentrations are used i.e. aqua regia exceeds $0.5 \mathrm{M}$, and in the presence of $\mathrm{H}_{2} \mathrm{O}_{2}$. 


\section{$B C R$ sequential extraction scheme}

The BCR sequential extraction scheme (BCR-SES), developed for labile metals in soils and sediments, was adopted to assess the mobility and bioavailability of As in the two urban soils. The process involves the use of reagents with different chemical nature (e.g. dilute acids, oxidising agents and reducing agents) to selectively extract target metals associated with fractions in a simple three-step sequential extraction procedure (Rauret et al. 1999).

A successful application of the modified BCR-SES was carried out on a reference material (BCR-701) and the results for the extraction test are presented in Table 3. To evaluate the modified BCR extraction procedure, a certified reference material BCR-701 was analysed and the recovery of the analytes against pseudo-total element content ranged from 86.6 $120 \%$, which is within the allowable range. The highest extractable As was observed in the second step (i.e. reducible fraction) suggesting that the majority of As fraction is bound to the Fe-Mn oxides. In addition, the $\mathrm{Cu}, \mathrm{Ni}$ and $\mathrm{Pb}$ soil contents also exhibited the highest extractable fractions in the second step of BCR-SES. The proportion of metal extracted in the first step (i.e. exchangeable fraction) was observed to be low for all the studied elements except $\mathrm{Cd}$. This suggests that the elements may be less mobile in the soil environment. However, all the results for the analysed elements are within the acceptable range of concentration of which the measured values can well be compared with the certified values.

To assess the chemical forms (speciation) of As in two urban sites, the BCR-SES was employed to extract 22 selected soil samples. Following the step-by-step protocol, the soil phases were extracted to release the As fractions. A selective dissolution of the As binding phases occurred in each of the steps leaving the less labile As in the residual fraction (Davidson et al. 1999; Van Herreweghe et al. 2003). Although, the BCR-SES method has not been validated for isolation of anionic species except $\mathrm{Cr}$, it can be a useful selective chemical 
extraction method for redox sensitive soil contaminants such as As, Se and Sb due to the series of reagents involved. In this study, the BCR-SES is used to complement the CISED extraction method to estimate the mobile (i.e. soluble) As fractions in the soil. This method uses mild oxidising and reducing agents due to redox sensitivity of As for distribution of the contaminants into different operationally defined fractions

Figure 5 summarises the proportion of As released in the various steps of the BCR-SES. The BCR-SES revealed that the highest proportion of As was released in the second step (i.e. reducible fraction) followed by the residual fraction in most of the soil samples. The reducible As fraction is often bound to the Fe-Mn oxyhydroxides in the soil. Due to the strong affinity of As to Fe-Mn oxyhydroxides, the reducible fraction of BCR-SES containing As bound to amorphous forms of Fe-oxides has been reported by several studies (Pueyo et al. 2003; Van Herreweghe et al. 2003; Cappuyns et al. 2007).

A higher residual As fraction in Site A soils is observed compared to Site B soils where the highest total As concentration $(24,900 \pm 994 \mathrm{mg} / \mathrm{kg})$ is found for both sites. This suggests that the majority of As extracted from the soil is less reactive. The residual fraction contains the refractory soil components that can only dissolve in strong acids. The high proportion of the residual fraction indicates that the As in this soil is less mobile and bioavailable in the environment. The BCR-SES data for all the test samples are shown in Table S6(A) for Site A and Table S6(B) for Site(B).

The exchangeable fraction contained As that varied between 7 and $8 \%$. The reducible fraction of As ranged between 28 and $54 \%$, while the oxidisable fraction varied between 5 and $6 \%$. Finally, the residual fraction contained As between 32 and $60 \%$ of the total As soil content (Figure 5). The reducible fraction with a significant amount of As (54\%) in the soil 
suggests that the majority of As is bound to the Fe-Mn oxide phase in Site B soils. In contrast, the highest proportion of As (60\%) was in the residual As fraction in Site A soils.

\section{Comparison of CISED and BCR-SES data}

The CISED extraction method has identified two distinct As-containing components (Fe-As-

Ca and As-Fe) from the two urban soils. The CISED extraction clearly estimates the distribution of the As among various solid phases, compared with the BCR-SES where As in the soil is only distributed into three different fractions. Since the solubility of an element is being controlled by the different composition of components, the proportion of As bound to each of the components can be compared to the reducible As fraction of BCR-SES. The highest proportion of As is extracted in the reducible fraction of BCR-SES. This result confirms the CISED extraction that As is strongly associated with Fe-oxides in the soil.

Tables $2(A+B)$ show the tentative geochemical assignment of the components identified by the CISED method. The Fe-As-Ca component obtained in Site A soils contributes to $84 \%$ total As content, which is higher than the reducible As fraction of $28 \%$ by BCR-SES. The reason for this difference is that the Fe-As-Ca component present in the soil is dominated by a residual As fraction. However, the reducible As fraction in Site B soil is $54 \%$ which is less than $78 \%$ of As extractable in As-Fe component. A high proportion of As in Site B soils is associated with amorphous Fe-oxide being the dominant phase in the reducible fraction of BCR-SES. It is important to note that the reducible As the fraction of BCR-SES is mainly associated with amorphous Fe-oxides while the CISED extraction is able to identify the composition of As-containing components across the sites.

The use of the CISED and BCR-SES methods has complemented each other in understanding the distribution of As in the soil. Further work is required however to 
characterise the As-bearing minerals and whether they are associated with crystalline and/or amorphous Fe-oxides in the soil.

\section{Analysis of selected samples by XRD}

The application of this technique is to identify crystalline mineral phases available in the test soils under investigation. This analytical approach could provide better understanding of the crystal chemical location of trace elements in mineral phases (Brown Jr and Calas, 2011). In this study, a total of 10 test soils made up of varying concentrations of As along with two CRMs were subjected to XRD analysis.

Soil samples selected for the XRD analysis were collected from Site B across different sampling locations. In order to determine the As-bearing minerals present in the samples, the analysed samples were chosen based on their total As concentrations ranging from 40 $24,900 \mathrm{mg} / \mathrm{kg}$. An initial screening of the test soils was carried out to determine the total As concentrations prior to the selection of the samples for XRD analysis. The XRD analysis was performed on field moist samples freshly collected from the sampling locations to identify the bulk mineralogy and heavy-media separates. The summary of the XRD data for the selected soil samples including two reference materials are presented in Table 4. The two reference materials (i.e. CRM059-50 and SRM 2710a) were made up of the dominant quartz $\left(\mathrm{SiO}_{2}\right)$ mineral followed by kaolinite $\left(\mathrm{Al}_{2}\left(\mathrm{Si}_{2} \mathrm{O}_{5}\right)(\mathrm{OH})_{4}\right)$, hematite $\left(\mathrm{Fe}_{2} \mathrm{O}_{3}\right)$, halite $(\mathrm{NaCl})$, albite ( $\left.\mathrm{NaAISi}_{3} \mathrm{O}_{8}\right)$, microcline $\left(\mathrm{KAISi}_{3} \mathrm{O}_{8}\right)$, muscovite $\left(\mathrm{KAl}_{2}\left(\mathrm{AlSi}_{3} \mathrm{O}_{10}\right)(\mathrm{F}, \mathrm{OH})_{2}\right)$, and jarosite $\left(\mathrm{KFe}_{3}(\mathrm{OH})_{6}\left(\mathrm{SO}_{4}\right)_{2}\right)$ with traces of chlorite $\left.(\mathrm{Mg}, \mathrm{Fe})_{3}(\mathrm{Si}, \mathrm{Al})_{4} \mathrm{O}_{10}\right)$, pyrite $\left(\mathrm{FeS}_{2}\right)$, calcite $\left(\mathrm{CaCO}_{3}\right)$, and magnesio-hornblende $\left(\mathrm{Ca} 2\left[(\mathrm{Mg} ; \mathrm{Fe})_{4} \mathrm{Al}\right]\left(\mathrm{Si}_{7} \mathrm{Al}\right) \mathrm{O}_{22}(\mathrm{OH})_{2}\right)$ all in varying proportions. The XRD data for the reference materials indicated that the soils are mainly composed of major silicate mineral (quartz), aluminosilicates (albite, microcline and muscovite), calcite, hematite and traces of other minerals. 
No As-bearing mineral was identified by the XRD, which is consistent with that observed for SRM 2710 soil by Cave et al. (2004). The comparison of XRD data for CRM 059 was not possible because no available data have been documented by this technique. All the minerals identified by the XRD are predominantly naturally occurring and are relatively abundant in the soil environment. However, the calcite and hematite minerals found in the two reference materials may be the major host to trace elements present in the soil. It is difficult to identify minerals bearing any trace element in the reference soils because they are below the limit of detection of this technique or non-crystalline / amorphous samples. Most of trace elements in soil may likely be less abundant whether they are derived from either anthropogenic or natural sources.

For the selected soil samples, the XRD data were made up of major, minor and trace mineral components (Table 4). The soil samples were dominated by abundant quartz and other minor minerals including albite, kaolinite, microcline, muscovite, hematite, mullite $\left(\mathrm{Al}_{2} \mathrm{O}_{3} \mathrm{SiO}_{2}\right)$, clinopyroxene ((Na,Al, $\left.\mathrm{Ca}, \mathrm{Mg}, \mathrm{Fe})_{2} \mathrm{SiO}_{6}\right)$ and calcite. While, traces of chlorite, ankerite $\left(\mathrm{Ca}(\mathrm{Fe}, \mathrm{Mg}, \mathrm{Mn})\left(\mathrm{CO}_{3}\right)_{2}\right)$, bassanite $\left(\left(\mathrm{CaSO}_{4} .0 .5 \mathrm{H}_{2} \mathrm{O}\right)\right.$, magnesio-hornblende and dolomite $\left(\mathrm{CaMg}\left(\mathrm{CO}_{3}\right)_{2}\right)$ were found in the soil samples. In Table 4, calcite and hematite were identified as major mineral component in 3 out of the 10 soil samples analysed by the XRD. Calcite and hematite minerals have been described as major hosts for As in contaminated soils (Cances et al. 2008; Zhao and Guo, 2014). It is noted that 2 soil samples (\#13 and \#15) dominated with calcite and hematite and have elevated level of As>1,000 mg/kg (Table 4).

Except for two other soil samples (\#14 and \#20), where hematite is found to be a minor mineral component, the As-enriched soil samples may be considered as being closely associated with hematite. It is noted that soil samples with high As concentrations have a relatively high proportion of hematite. The elevated As soil contents may be attributed to adsorption of As on the surfaces of hematite solid phase mineral. In this study, the XRD 
analysis could not lead to the identification of any As-bearing minerals or other amorphous minerals present in the soil samples. It is therefore, important that further investigation be carried out to establish whether the As-bearing minerals exist in amorphous forms.

\section{Analysis of selected soil samples by micro-Raman spectroscopy}

A micro-Raman spectrometer was employed to identify minerals in four selected soil samples. The soil samples were collected from Site B because of their elevated As soil contents for the identification of As-bearing minerals. Using the micro-Raman spectrometer as a non-destructive technique, the chemical composition of the mineral phases present in each of the investigated soils was identified. The importance of this approach is to complement the conventional bulk analysis undertaken by the XRD technique. Spectral identification was done using an in-house spectral library for the iron oxides, the RRUFF database and a commercially available spectral library via Spectracalc software (GRAMS, Galactic Industries).

Table 5 summarises the major, minor and trace mineralogical components identified in the soil samples. The Raman spectra bands for quartz were identified as the dominant Si-rich mineral component observed in all the samples. Minor mineral components of the aluminosilicate (feldspar), calcite and hematite were identified along with traces of other minerals such as pharmacosiderite $\left(\mathrm{KFe}_{4}\left[\left(\mathrm{H}_{2} \mathrm{O}\right)_{4}\left(\mathrm{AsO}_{4}\right)_{3}\right] .6 \mathrm{H}_{2} \mathrm{O}\right)$, pyrrhotite $\left(\mathrm{Fe}_{7} \mathrm{~S}_{8}\right)$, goethite ( $\alpha$ $\mathrm{FeO}(\mathrm{OH}))$, martite $\left(\alpha-\mathrm{Fe}_{2} \mathrm{O}_{3}\right)$, magnetite $\left(\mathrm{Fe}_{3} \mathrm{O}_{4}\right)$, rutile $\left(\mathrm{TiO}_{2}\right)$, muscovite $\left(\mathrm{KAl}_{2}\left(\mathrm{AlSi}_{3} \mathrm{O}_{10}\right)(\mathrm{F}, \mathrm{OH})_{2}\right)$, chromite $\left(\mathrm{FeCr}_{2} \mathrm{O}_{4}\right)$, psilomelane $\left.\left(\mathrm{Ba}, \mathrm{H}_{2} \mathrm{O}\right)_{2} \mathrm{Mn}_{5} \mathrm{O}_{10}\right)$, mimetite $\left(\mathrm{Pb}_{5}\left(\mathrm{AsO}_{4}\right)_{3} \mathrm{Cl}\right)$, gypsum $\left(\mathrm{CaSO}_{4} \cdot \mathrm{H}_{2} \mathrm{O}\right)$ and amorphous carbon (soot). Pharmacosiderite and mimetite have been identified as As-bearing mineral phases in highly contaminated soils by previously reported studies (Filippi et al. 2007; Frost and Kloprogge, 2003). 
The soil samples containing Fe-rich minerals such as hematite, goethite and pyrrhotite may be considered as the major host of As in the soil matrix. Although, sample \#16 has the highest total As concentration, the mimetite $\left(\mathrm{Pb}_{5}\left(\mathrm{AsO}_{4}\right)_{3} \mathrm{Cl}\right)$ mineral is not directly associated with Fe-oxides in the soil. However, traces of hematite have been identified in this sample by the XRD technique. In contrast, the Raman data for sample \#13 includes a minor hematite with pharmacosiderite $\left(\mathrm{KFe}_{4}\left[\left(\mathrm{H}_{2} \mathrm{O}\right)_{4}\left(\mathrm{AsO}_{4}\right)_{3}\right] \cdot 6 \mathrm{H}_{2} \mathrm{O}\right)$ as the As-bearing minerals. This suggests that a close relationship exists between As and Fe-oxides in the soil matrix. The As-bearing minerals were mainly characterised by their chemical compositions with varying proportions of $\mathrm{As}, \mathrm{Fe}, \mathrm{Pb}$ and other elements. The soil sample (\#13) containing the pharmacosiderite may likely be formed by the association between As and Fe-oxides (hematite). In contrast, the mimetite in sample \#16 accounts for the elevated $\mathrm{Pb}$ soil content that coexists with high As concentration in the soil. The Raman signal of $813 \mathrm{~cm}^{-1}$ for identification of pharmacosiderite has been reported in a previous study (Cances et al. 2008). Since, it is difficult to identify As-bearing minerals by the micro-Raman analysis in all the soil samples, further investigation may be useful to detect the As-rich particles in the soil.

\section{Individual particle analysis using SEM-EDX}

SEM-EDX analysis was performed on eight selected soil samples to identify and characterise As-rich particles. Four soil samples were chosen per site comprising two samples of low and high As concentrations, respectively. The high As concentration ranged from $911-24,900$ $\mathrm{mg} / \mathrm{kg}$ (Site B) for the four soil samples while those with low As concentrations varied between 40.2 and $144 \mathrm{mg} / \mathrm{kg}$ (Site A). To characterise the individual microscopic particles, the SEM-EDX was set up to collect data on the As-enriched soil samples. A total of 1000 individual particles were characterised to provide the elemental composition data. A set of elements comprising 16 major and trace elements (Al, $\mathrm{As}, \mathrm{Ca}, \mathrm{Cu}, \mathrm{Fe}, \mathrm{K}, \mathrm{Mg}, \mathrm{Mn}, \mathrm{Na}, \mathrm{Ni}, \mathrm{P}$, $\mathrm{Pb}, \mathrm{S}, \mathrm{Si}, \mathrm{Ti}$ and $\mathrm{Zn}$ ) were determined. In terms of the different particle compositions in each 
sample, a large SEM-EDX dataset was produced and reduced into 11 key compositional groups based on \% elemental abundance. Due to spectra interference on As, only particles with $>10 \%$ abundance of As were allocated to the As-rich group.

To evaluate the method, SEM-EDX analysis was carried out on SRM 2710a and is compared with a previous study on SRM 2710 soil (Cave et al. 2004). The SEM-EDX data for the SRM 2710a and SRM 2710 soils are presented in Table S7. The SEM-EDX revealed the various classes of $\mathrm{Pb}$ and $\mathrm{Zn}$ components present in the soil matrix. Four major components were identified in the $\mathrm{Pb}$ and $\mathrm{Zn}$-rich particles that can be compared with the previous study on the SRM 2710 soil. The Zn-S and Pb-Si particles were common in all the components identified in the present study. In comparison, the Zn-S has been identified in SRM 2710 by SEM-EDX analysis in a previous study (Cave et al. 2004). The results suggest that the Zn-S may have been derived from sphalerite. The SEM-EDX particle distribution of $\mathrm{Pb}$ and $\mathrm{Zn}$ in SRM 2710a are closely related to the mineralogy of SRM 2710 soil (Table S7). A high proportion of $\mathrm{Pb}$ and $\mathrm{Zn}$ in the reference materials may probably be obtained from sphalerite and galena minerals, respectively. From the SEM-EDX data on the SRM 2710a soil, the technique can be used to identify metal-rich particles in soil samples. The summary of the distribution of the compositional classes in the individual soil particles is presented in Table S7.

A total of 5 out of the 8 selected soil samples were found to have dominant As-Fe particles. The highest As-rich particles were found in sample \#13 while the lowest As-rich particles were found in sample \#22. As-rich particles are common in samples with elevated As contents whereas Si-rich particles are found in samples with low As content. The As-Pb particles in the samples tend to occur only in the As-enriched soils (Figure 6). Figure 6 confirms that $\mathrm{Pb}$ coexists with As in the soil and is in close agreement with the Raman data that identified a Pb-bearing mineral (mimetite) in one of the samples (Table 5). The dominant 
class was found to be the As-rich particles bound to Fe particles. The results are in good agreement that As is closely associated with Fe-oxides in soil (Smedley and Kinniburgh, 2002; Drahota and Filippi, 2009; Cances et al. 2005).

For each field of view, the SEM-EDX displays spectra of the dominant elements identified at the individual particle level (Figure 7). It shows that the individual particle is composed of trace and major elements present in the soil. The SEM-EDX analysis is a useful approach to improve the understanding of the association between As and other elements in the soil matrix. It provides an additional line of evidence to support the data obtained from XRD and micro-Raman techniques.

It is important to note that the association of As with Fe-oxides across the sites is the driving force of As mobility and bioavailability. The study of mineralogy of As-enriched soils has improved the understanding of the different chemical forms of the contaminant that exist within the former industrial sites (Table 6). The release of As into solution becomes difficult when there is a strong interaction between As and the solid phase minerals (Fe-oxide and carbonate). When As is immobilised in the soil, the potential risks posed by the contaminant is reduced. However, the elevated As concentrations in the soil does pose a significant possibility of significant harm (SPOSH) which needs to be managed to reduce human activity on the individual site.

\section{Conclusions}

The high As concentrations found in the urban soil samples from two current housing sites i.e. $126-1,660 \mathrm{mg} / \mathrm{kg}$ (Site A) and $40-24,900 \mathrm{mg} / \mathrm{kg}$ (Site B), exceed in all cases the C4SL of $37 \mathrm{mg} / \mathrm{kg}$ for As in a residential area with home grown produce. On that basis the two sites could pose a significant risk to human health for on-site residents due to the high levels of 
pseudo-total As in the soil. However, despite the exceedance of soil concentration of As over the critical concentration it is always important to apply caution because site-specific circumstances such as site-usage and activities of the receptors needs to be taken into account in order to assess the actual human health risks. In this work, and to complement the site-specific circumstances, additional approaches have been used. Specifically, the use of chemical extraction and analytical structural techniques have been used to assess the mobility and availability of As in the urban soils.

The sequential extraction methods have identified Fe oxides as a major host to As in the matrix. The CISED extraction methods identified 16 distinct physicochemical components including two As-containing components mainly Fe-As-Ca and As-Fe components from Site A and Site B soils, respectively. Using the BCR-SES, the findings have shown that the As extracted from the reducible fraction are more likely derived from the amorphous Fe oxides phase. In addition, the use of multi-analytical techniques has confirmed the results obtained from the sequential chemical extractions by identifying the association of As and Fe in the soil. In this study, two As-bearing minerals (pharmacosiderite and mimetite) were identified using Raman spectrometry. For As-rich particles, the As-Fe component was commonly found in the soil samples analysed by the SEM-EDX technique.

It is therefore concluded that the high levels of As, present across both sites, could pose a significant possibility of significant harm. However, this study has identified the incalcitrant nature and lack of mobility of As due to its strong interaction with mineral phases. Never the less, human endeavour and activities on the individual sites could increase the risk of significant harm due to soil disturbance and contact with the soil. It is therefore proposed that 
the soil remain inactive e.g. front gardens with paved areas and/or driveways, and rear gardens with patios, to minimalize the human health risk.

\section{Acknowledgements}

The Niger Delta Development Commission (NDDC), Nigeria without whose financial support this research would not have been possible. The authors would like to thank Andrew Hunt (UTArlington) for support and guidance with the SEM-EDX work. MC and SJK publish with the permission of the Executive Director, British Geological Survey (UKRI).

\section{References}

Appleton JD, Cave MR, Wragg J (2012) Anthropogenic and geogenic impacts on arsenic bioaccessibility in UK topsoils. The Science of the Total Environment 435-436: 21-29.

ATSDR (2007) Toxicological profile for arsenic Agency for Toxic Substances and Disease Registry, Division of Toxicology, Atlanta, GA. Available:

http://www.atsdr.cdc.gov/ToxProfiles/tp.asp?id=22\&tid=3 [accessed : 7 November, 2015].

ATSDR (2009) Case studies in Environmental medicine: Arsenic toxicity, Agency for Toxic Substances and Disease Registry, Division of Toxicology.

Bacon JR, Davidson CM (2008) Is there a future for sequential chemical extraction? Analyst 133:25-46.

Basta NT, Foster JN, Dayton EA, Rodriguez RR, Casteel SW (2007) The effect of dosing vehicle on arsenic bioaccessibility in smelter-contaminated soils. Journal of Environmental Science and Health, Part A 42: 1275-1281.

British Standard Institute (BSI) (1997): Determination of particle size distribution - sieving method in BS933 - 1.

Brown Jr GE, Calas G (2011) Environmental mineralogy - Understanding element behaviour in ecosystems. Comptes Rendus Geoscience 343(2-3): 90-112. 
Cancès B, Juillot F, Morin G, Laperche V, Alvarez L, Proux O, Hazemann JL, Brown GE, Calas G (2005) XAS Evidence of As(V) Association with Iron Oxyhydroxides in a Contaminated Soil at a Former Arsenical Pesticide Processing Plant. Environmental Science and Technology 39(24): 9398-9405.

Cancès B, Juillot F, Morin G, Laperche V, Polya D, Vaughan DJ, Hazemann JL, Proux O, Brown Jr GE, Calas G (2008) Changes in arsenic speciation through a contaminated soil profile: A XAS based study. Science of the Total Environment 397(1-3): 178-189.

Cappuyns V, Swennen R, Niclaes M (2007) Application of the BCR sequential extraction scheme to dredged pond sediments contaminated by $\mathrm{Pb}-\mathrm{Zn}$ mining: a combined geochemical and mineralogical approach. Journal of Geochemical Exploration 93(2): 78-90.

Cave, MR, Wragg J, Denys S, Jondreville C, Freidt C (2011) Oral bioavailability. In: Swartjes $\mathrm{F}(\mathrm{Ed})$, Dealing with contaminated sites from theory towards practical application. Springer. Dordrecht, 287 - 324.

Cave M, Wragg J, Gowing C, Gardner A (2015) Measuring the solid-phase fractionation of lead in urban and rural soils using a combination of geochemical survey data and chemical extractions. Environmental Geochemistry and Health 37: 779-790.

Cave M, Wragg J, Palumbo B, Klinck B (2003) Measurement of the bioaccessibility of arsenic in UK soils. Environment Agency, Bristol, UK.

Cave MR, Milodowski AE, Friel EN (2004) Evaluation of a method for identification of host physico-chemical phases for trace metals and measurement of their solid-phase partitioning in soil samples by nitric acid extraction and chemometric mixture resolution. Geochemistry: Exploration, Environment, Analysis 4(1): 71-86.

Chen YN, Ding LC, Liu CH (2013) Review of the treatment of water containing arsenic. In: Applied Mechanics and Materials Trans Tech Publication 1162-1166.

CL:AIRE (2014) SP1010 - Development of Screening Levels for Assessment of Land affected by Contamination. Final Project Report (Revision 2).

Cornell R, Schwertmann U (1996) The iron oxides - Structure, Properties, Occurrence and uses. VCH. Weinheim, Germany. 
Da Sacco L, Baldassarre A, Masotti A (2013) Diet's role in the toxicity of inorganic arsenic (iAs): A journey from soil to children's mouth. Journal of Geochemical Exploration 131:45-51 .

Daus B, Mattusch J, Paschke A, Wennrich R, Weiss H (2000) Kinetics of the arsenite oxidation in seepage water from a tin mill tailings pond. Talanta 51: 1087-1095.

Davidson CM, Ferreira PC, Ure AM (1999) Some sources of variability in application of the three-stage sequential extraction procedure recommended by BCR to industriallycontaminated soil. Fresenius' journal of analytical chemistry 363(5-6): 446-451.

DEFRA and Environment Agency (2002) Contaminants in soil: collation of toxicological data intake values for humans, Lead R \&D Publication TOX 6 (Withdrawn).

Denys S, Caboche J, Tack K, Rychen G, Wragg J, Cave M, Jondreville C, Feidt C (2012) In Vivo Validation of the Unified BARGE Method to Assess the Bioaccessibility of Arsenic, Antimony, Cadmium, and Lead in Soils. Environmental Science \& Technology 46: 62526260 .

DIN, Deutsches Institut fur Normung e.V. (2000): Soil quality - absorption availability of organic and inorganic pollutants from contaminated soil material. DIN E 19738.

Drahota P, Filippi M (2009) Secondary arsenic minerals in the environment: A review. Environment International 35(8): 1243-1255.

Drexler JW (1999): Standard Operating Procedure for In vitro bioaccessibility leaching. University of Colorado at Boulder.

Fendorf S, La Force MJ, Li G (2004) Temporal changes in soil partitioning and bioaccessibility of arsenic, chromium, and lead. Journal of Environmental Quality 33: 20492055.

Filgueiras AV, Lavilla I, Bendicho C (2002) Chemical sequential extraction for metal partitioning in environmental solid samples. Journal of Environmental Monitoring 4: 823-857.

Filippi M, Doušová B, Machovič V (2007) Mineralogical speciation of arsenic in soils above the Mokrsko-west gold deposit, Czech Republic. Geoderma 139(1):154-170. 
Fitz WJ, Wenzel WW (2002) Arsenic transformations in the soil-rhizosphere-plant system: fundamentals and potential application to phytoremediation. Journal of Biotechnology 99: 259-278.

Frost RL, Kloprogge JT (2003) Raman spectroscopy of some complex arsenate mineralsimplications for soil remediation. Spectrochimica Acta Part A: Molecular and Biomolecular Spectroscopy 59(12): 2797-2804.

Hack A, Selenka F (1996): Mobilisation of PAH and PCB from contaminated soil using a digestive treat model. Toxicology Letter 88: 199 -210.

IARC (2004) Monographs on the Evaluation of Carcinogenic Risks to Humans. Volume 84. International Agency for Research on Cancer: Lyon.

Juhasz AL, Smith E, Nelson C, Thomas DJ, Bradham K (2014) Variability associated with As in vivo-in vitro correlations when using different bioaccessibility methodologies.

Environmental Science \& Technology 48(19): 11646-11653.

Juhasz AL, Smith E, Weber J, Rees M, Rofe A, Kuchel T, Sansom L, Naidu R. (2007) In vitro assessment of arsenic bioaccessibility in contaminated (anthropogenic and geogenic) soils. Chemosphere 69: 69-78.

Kabata-Pendias A (2010) Trace elements in soils and plants. $4^{\text {th }}$ edition. Boca Raton, CRC Press, USA.

Kelley ME, Braunning SE, Schoof R, Ruby MV (2000) Assessing oral bioavailability of metals in soil. Battelle Press. Columbus $-\mathrm{OH}$.

Kim M-J, Ahn K-H, Jung Y (2002) Distribution of inorganic arsenic species in mine tailings of abandoned mines from Korea. Chemosphere 49: 307-312.

Mandal Bk, Suzuki KT (2002) Arsenic round the world: a review. Talanta 58(1): 201 -235.

Palumbo-Roe B, Wragg J, Cave M (2015) Linking selective chemical extraction of iron oxyhydroxides to arsenic bioaccessibility in soil. Environmental Pollution 207: 256-265.

Popovic A, Djordjevic D, Polic P (2001) Trace and major element pollution originating from coal ash suspension and transport processes. Environment International 26: 251-255. 
Pueyo M, Sastre J, Hernandez E, Vidal M, Lopez-Sanchez J, Rauret G (2003) Prediction of trace element mobility in contaminated soils by sequential extraction. Journal of Environmental Quality 32(6): 2054-2066.

Rao C, Sahuquillo A, Sanchez JL (2008) A review of the different methods applied in environmental geochemistry for single and sequential extraction of trace elements in soils and related materials. Water Air Soil Pollut 189: 291-333.

Rauret G, Lopez-Sanchez J, Sahuquillo A, Rubio R, Davidson C, Ure A, Quevauviller P (1999) Improvement of the BCR three step sequential extraction procedure prior to the certification of new sediment and soil reference materials. Journal of Environmental Monitoring 1: 57-61.

Rodriguez RR, Basta NT, Casteel SW, Armstrong FP, Ward DC (2003) chemicalextraction-methods-to-assess-bioavailable-arsenic-in-soil-and-solid-media . Journal of Environment Quality 32: 876-884.

Rodriguez RR, Basta NT, Casteel S, Pace L (1999) An in vitro gastrointestinal method to estimate bioavailable arsenic in contaminated soils and solid media. Environmental Science and Technology 33: $642-649$.

Ruby MV, Davis A, Link TE, Schoof R, Chaney RL, Freeman GB, Bergstrom P (1993) Development of an in vitro screening test to evaluate the in vivo bioaccessibility of ingested mine-waste lead. Environmental Science \& Technology 27: 2870-2877.

Ruby MV, Davis A, Schoof R, Eberle S, Sellstone CM (1996) Estimation of lead and arsenic bioavailability using a physiologically based extraction test. Environmental Science \& Technology 30: 422-430.

Sahuquillo A, Rigol A, Rauret G (2003) Overview of the use of leaching/extraction tests for risk assessment of trace metals in contaminated soils and sediments. TrAC Trends in Analytical Chemistry 22: 152-159.

Schroder JL, Basta NT, Si JT, Casteel SW, Evans T, Payton M (2003) In vitro gastrointestinal to estimate bioavailable Cadmium in contaminated soil. Environmental Science and Technology 37: $1365-1370$. 
Smedley P, Kinniburgh D (2002) A review of the source, behaviour and distribution of arsenic in natural waters. Applied Geochemistry 17(5): 517-568.

Swartjes F (2011) Introduction to Contaminated Site Management. In: Swartjes FA (ed) Dealing with Contaminated Sites. Springer Netherlands, 3-89

Tessier A, Campbell PG, Bisson M (1979) Sequential extraction procedure for the speciation of particulate trace metals. Analytical Chemistry 51:844-851.

Van Herreweghe S, Swennen R, Vandecasteele C, Cappuyns V (2003) Solid phase speciation of arsenic by sequential extraction in standard reference materials and industrially contaminated soil samples. Environmental Pollution 122(3):323-342.

Wenzel WW, Kirchbaumer N, Prohaska T, Stingeder G, Lombi E, Adriano DC (2001) Arsenic fractionation in soils using an improved sequential extraction procedure. Analytica Chimica Acta 436: 309-323.

WHO (2001) Arsenic compounds (Compounds, Environmental Health Criteria 224 World Health Organisation, Geneva.

Wragg J, Cave M (2012) Assessment of a geochemical extraction procedure to determine the solid phase fractionation and bioaccessibility of potentially harmful elements in soils: a case study using the NIST 2710 reference soil. Analytica Chimica Acta 722: 43-54.

Wragg J, Cave M, Basta N, Brandon E, Casteel S, Denys S, Gron C, Oomen A, Reimer K, Tack K, Van de Wiele T (2011) An inter-laboratory trial of the unified BARGE bioaccessibility method for arsenic, cadmium and lead in soil. Science of the Total Environment 409: 40164030.

Wragg J, Cave M, Nathanail P (2007) A Study of the relationship between arsenic bioaccessibility and its solid-phase distribution in soils from Wellingborough, UK. Journal of Environmental Science and Health, Part A 42: 1303-1315.

Yang J-K, Barnett MO, Jardine PM, Basta NT, Casteel SW (2002) Adsorption, sequestration, and bioaccessibility of As (V) in soils. Environmental Science \& Technology 36: 4562-4569. 
Zhao K, Guo H (2014) Behaviour and mechanism of arsenate adsorption on activated natural siderite: evidences from FTIR and XANES analysis. Environmental Science and Pollution Research 21(3): 1944-1953. 
Table 1. Sampling depth, soil properties and total concentration $(\mathrm{mg} / \mathrm{kg})$ of PHEs from Sites A and B

\begin{tabular}{|c|c|c|c|c|c|c|c|c|c|c|}
\hline aSample & Depth & $\mathrm{pH}^{\mathrm{b}}$ & $\%$ TOC $^{\mathrm{C}}$ & $\begin{array}{c}\text { CEC }^{d} \\
\text { (cmol/kg) }\end{array}$ & Soil Texture & As & Cd & $\mathrm{Cr}$ & $\mathbf{N i}$ & $\mathbf{P b}$ \\
\hline \#1 & 0.20 & 7.2 & 18.9 & $17.1 \pm 0.4$ & sandy loam & $221 \pm 7$ & $6.1 \pm 0.3$ & $29.8 \pm 1.5$ & $43.4 \pm 1.3$ & $339 \pm 12$ \\
\hline \#2 & 0.20 & 7.2 & 12.6 & $15.8 \pm 1.6$ & sandy loam & $251 \pm 10$ & $7.6 \pm 0.6$ & $25.7 \pm 2.6$ & $38.5 \pm 0.6$ & $382 \pm 7$ \\
\hline \#3 & 0.20 & 7.0 & 11.1 & $11.9 \pm 2.9$ & loamy sand & $144 \pm 2$ & $4.8 \pm 0.1$ & $27.4 \pm 0.3$ & $45.6 \pm 0.6$ & $469 \pm 9$ \\
\hline$\# 4$ & 0.50 & 6.6 & 8.3 & $7.5 \pm 0.3$ & loamy sand & $126 \pm 5$ & $2.8 \pm 0.1$ & $21.7 \pm 0.4$ & $28.6 \pm 0.90$ & $149 \pm 5$ \\
\hline \#5 & 0.60 & 6.6 & 9.1 & $15.3 \pm 0.6$ & loamy sand & $169 \pm 4$ & $5.6 \pm 0.1$ & $68.6 \pm 3.3$ & $43.1 \pm 2.2$ & $369 \pm 8$ \\
\hline \#6 & 0.50 & 7.4 & 19.1 & $14.7 \pm 1.0$ & sand & $451 \pm 7$ & $4.7 \pm 0.1$ & $30.8 \pm 1.7$ & $51.6 \pm 1.3$ & $385 \pm 10$ \\
\hline$\# 7$ & 0.20 & 6.6 & 12.6 & $12.0 \pm 2.0$ & sandy loam & $169 \pm 5$ & $2.1 \pm 0.1$ & $23.9 \pm 0.8$ & $30.7 \pm 1.3$ & $226 \pm 7$ \\
\hline \#8 & 0.20 & 7.1 & 11.6 & $12.2 \pm 1.6$ & loamy sand & $147 \pm 5$ & $3.7 \pm 0.2$ & $31.7 \pm 0.6$ & $47.4 \pm 0.1$ & $345 \pm 12$ \\
\hline$\# 9$ & 0.20 & 6.3 & 12.3 & $11.0 \pm 1.0$ & sand & $530 \pm 17$ & $4.9 \pm 0.1$ & $38.4 \pm 1.1$ & $54.8 \pm 0.7$ & $404 \pm 4$ \\
\hline \#10 & 0.50 & 7.4 & 17.0 & $14.5 \pm 0.3$ & sandy loam & $911 \pm 5$ & $5.8 \pm 0.1$ & $79.5 \pm 2.1$ & $49.0 \pm 1.2$ & $965 \pm 26$ \\
\hline$\# 11$ & 0.50 & 6.5 & 10.8 & $13.4 \pm 0.8$ & sandy loam & $1660 \pm 43$ & $4.1 \pm 0.2$ & $97.2 \pm 0.6$ & $40.1 \pm 0.7$ & $627 \pm 18$ \\
\hline$\# 12$ & 0.30 & 6.7 & 6.9 & $10.2 \pm 0.3$ & sandy loam & $364 \pm 7$ & $2.8 \pm 0.2$ & $30.0 \pm 0.9$ & $32.7 \pm 0.1$ & $398 \pm 12$ \\
\hline$\# 13$ & 0.10 & 5.38 & 14.6 & $11.0 \pm 1.0$ & Loamy sand & $5280 \pm 63$ & $12 \pm 1$ & $38.2 \pm 2.2$ & $66.7 \pm 3.4$ & $5930 \pm 325$ \\
\hline \#14 & 0.20 & 5.98 & 13.0 & $12.5 \pm 0.5$ & Sandy loamy & $514 \pm 10$ & $4.4 \pm 0.2$ & $43.2 \pm 0.4$ & $59.2 \pm 0.4$ & $720 \pm 26$ \\
\hline \#15 & 0.50 & 6.78 & 14.3 & $26.9 \pm 0.8$ & Sandy loamy & $2680 \pm 42$ & $7.5 \pm 0.3$ & $51.6 \pm 0.3$ & $87.7 \pm 1.5$ & $1870 \pm 34$ \\
\hline$\# 16$ & 0.20 & 6.69 & 12.4 & $45.0 \pm 2.3$ & Loamy sand & $24900 \pm 994$ & $1.22 \pm 0.17$ & $75.2 \pm 1.3$ & $52.6 \pm 1.5$ & $1980 \pm 51.6$ \\
\hline$\# 17$ & 0.20 & 7.10 & 13.3 & $21.1 \pm 0.4$ & Loamy sand & $2700 \pm 35$ & $4.65 \pm 0.15$ & $44.5 \pm 1.3$ & $49.1 \pm 1.4$ & $1530 \pm 32.9$ \\
\hline \#18 & 0.10 & 5.79 & 13.2 & $10.1 \pm 0.9$ & Loamy sand & $325 \pm 28$ & $2.62 \pm 0.19$ & $34.8 \pm 1.6$ & $46.4 \pm 0.6$ & $512 \pm 2.1$ \\
\hline$\# 19$ & 0.20 & 5.67 & 8.2 & $6.6 \pm 0.5$ & Loamy sand & $287 \pm 15$ & $0.38 \pm 0.07$ & $26.2 \pm 0.4$ & $25.8 \pm 0.1$ & $459 \pm 17.4$ \\
\hline
\end{tabular}




\begin{tabular}{|c|c|c|c|c|c|c|c|c|c|c|}
\hline \#20 & 0.20 & 6.78 & 20.5 & $29.5 \pm 1.1$ & Loamy sand & $614 \pm 16$ & $2.53 \pm 0.22$ & $34.9 \pm 0.8$ & $67.5 \pm 1.6$ & $535 \pm 20.0$ \\
\hline \#21 & 0.20 & 5.24 & 5.3 & $4.1 \pm 0.2$ & Sandy loam & $40 \pm 2$ & $0.08 \pm 0.1$ & $20.3 \pm 0.9$ & $23.9 \pm 0.5$ & $193 \pm 3.5$ \\
\hline \#22 & 0.20 & 6.95 & 10.1 & $7.2 \pm 0.5$ & Loamy sand & $93 \pm 4$ & $0.91 \pm 0.06$ & $20.3 \pm 0.1$ & $20.8 \pm 1.1$ & $246 \pm 2.6$ \\
\hline
\end{tabular}

aSamples \#1 - \#12 were collected from Site A and Samples \#13 - \#22 were collected from Site B.

${ }^{b}$ measured on $<2 \mathrm{~mm}$ soil fraction.

c Total Organic Carbon (TOC) was measured on $<250 \mu \mathrm{m}$ soil fraction.

${ }^{d}$ Cation Exchange Capacity (CEC) was measured on $<250 \mu \mathrm{m}$ soil fraction. 
Table 2. Tentative geochemical assignment of components identified in (A) Site $A$ and (B) Site B by CISED

(A)

\begin{tabular}{|c|c|c|c|c|}
\hline $\begin{array}{c}\text { Constituent } \\
\text { number }\end{array}$ & $\begin{array}{c}\text { Composition } \\
\text { names (based on } \\
>10 \% \text { elemental } \\
\text { presence) }\end{array}$ & $\begin{array}{l}\text { Geochemical } \\
\text { assignment }\end{array}$ & $\begin{array}{c}\text { Associated } \\
\text { As } \\
\text { distribution } \\
(\%)\end{array}$ & $\begin{array}{c}\text { Associated } \\
\text { As } \\
\text { distribution } \\
\text { (mg/kg) }\end{array}$ \\
\hline 1 & Ca-Mg & Carbonate & 0.0 & 0.0 \\
\hline 2 & K-Al-Si-Mg & Alumino-silicate & 1.1 & 35 \\
\hline 3 & Al-Mn & Mn oxide & 0.6 & 21 \\
\hline 4 & Fe-Si-Al & Alumino-silicate & 4.8 & 157 \\
\hline 5 & $\mathrm{Na}-\mathrm{Ca}$ & Exchangeable & 0.0 & 0.0 \\
\hline 6 & Ca-Si-Al-Fe & Alumino-silicate & 0.0 & 0.0 \\
\hline 7 & Ca-Al & Carbonate & 0.0 & 0.0 \\
\hline 8 & $\mathrm{Ca}$ & Carbonate & 0.0 & 0.0 \\
\hline 9 & Fe-As-Ca & Fe-Ca arsenate & 84 & 2760 \\
\hline 10 & $\mathrm{P}$ & Phosphate & 0.6 & 19 \\
\hline 11 & $\mathrm{Fe}$ & Fe oxide & 1.6 & 51 \\
\hline 12 & Ca-S & Pore-water & 0.0 & 0.0 \\
\hline 13 & Ca-S-Fe & Sulphate & 0.0 & 0.0 \\
\hline 14 & $\mathrm{Al}-\mathrm{Fe}$ & $\mathrm{Al}$ - Fe oxide & 6.1 & 202 \\
\hline 15 & Al-Ba & Al oxide & 1.4 & 47 \\
\hline 16 & Ca-Mn & Carbonate & 0.0 & 0.0 \\
\hline
\end{tabular}

(B)

\begin{tabular}{|c|c|c|c|c|}
\hline $\begin{array}{c}\text { Constituent } \\
\text { number }\end{array}$ & $\begin{array}{c}\text { Composition } \\
\text { names (based on } \\
\mathbf{7} \mathbf{1 0} \text { elemental } \\
\text { presence) }\end{array}$ & $\begin{array}{c}\text { Geochemical } \\
\text { assignment }\end{array}$ & $\begin{array}{c}\text { Associated } \\
\text { As } \\
\text { distribution } \\
\mathbf{( \% )}\end{array}$ & $\begin{array}{c}\text { Associated } \\
\text { As } \\
\text { distribution } \\
\text { (mg/kg) }\end{array}$ \\
\hline 1 & $\mathrm{Ca}-\mathrm{Na}$ & Exchangeable & 0.0 & 0.0 \\
\hline 2 & $\mathrm{Fe}-\mathrm{Al}$ & Fe oxide & 0.2 & 104 \\
\hline 3 & $\mathrm{Mn}-\mathrm{Al}$ & Mn oxide & 0.0 & 0.0 \\
\hline 4 & $\mathrm{Ca}-\mathrm{Zn}$ & Carbonate & 0.9 & 332 \\
\hline 5 & $\mathrm{~K}-\mathrm{Mg}$ & Exchangeable & 0.1 & 34 \\
\hline 6 & $\mathrm{Si}-\mathrm{Mg}-\mathrm{Zn}$ & Silicate & 0.0 & 0.0 \\
\hline 7 & $\mathrm{~Pb}-\mathrm{Al}-\mathrm{Ca}$ & Pb oxide & 4.5 & 1610 \\
\hline 8 & $\mathrm{Ca}$ & Carbonate & 0.5 & 168 \\
\hline 9 & $\mathrm{Fe}$ & Fe oxide & 15.6 & 5540 \\
\hline 10 & $\mathrm{Ca}-\mathrm{Al}-\mathrm{Si}$ & Alumino-silicate & 0.0 & 0.0 \\
\hline 11 & $\mathrm{Mn}-\mathrm{Zn}$ & Mn oxide & 0.0 & 0.0 \\
\hline 12 & $\mathrm{Mn}$ & Mn oxide & 0.0 & 0.0 \\
\hline 13 & $\mathrm{~S}-\mathrm{Ca}$ & Pore-water & 0.1 & 45 \\
\hline 14 & $\mathrm{As}-\mathrm{Fe}$ & Fe-arsenate & 78 & 27600 \\
\hline 15 & $\mathrm{Ca}-\mathrm{Mn}$ & Carbonate & 0.6 & 215 \\
\hline 16 & $\mathrm{P}-\mathrm{Al}-\mathrm{Ca}$ & Phosphate & 0.0 & 0.0 \\
\hline
\end{tabular}


Table 3. BCR-701 extractable trace metal contents $(\mathrm{mg} / \mathrm{kg})$ determined by the modified BCR-SES method

\begin{tabular}{|c|c|c|c|c|c|c|c|c|c|c|c|c|c|}
\hline \multirow{2}{*}{ Element } & \multicolumn{3}{|c|}{ Step 1} & \multicolumn{3}{|c|}{ Step 2} & \multicolumn{3}{|c|}{ Step 3} & \multirow{2}{*}{$\begin{array}{l}\text { Residual } \\
\text { fraction }\end{array}$} & \multirow{2}{*}{$\begin{array}{c}\Sigma 3 \\
\text { steps + } \\
\text { residual }\end{array}$} & \multirow{2}{*}{$\begin{array}{l}\text { Pseudo- } \\
\text { total }\end{array}$} & \multirow{2}{*}{$\begin{array}{c}\% \\
\text { Recovery }\end{array}$} \\
\hline & $\begin{array}{l}\text { Measured } \\
\text { value }\end{array}$ & $\begin{array}{c}\text { Certified } \\
\text { value }\end{array}$ & $\begin{array}{c}\% \\
\text { recovery }\end{array}$ & $\begin{array}{l}\text { Measured } \\
\text { value }\end{array}$ & $\begin{array}{c}\text { Certified } \\
\text { value }\end{array}$ & $\begin{array}{c}\% \\
\text { recovery } \\
\end{array}$ & $\begin{array}{c}\text { Measured } \\
\text { value }\end{array}$ & $\begin{array}{l}\text { Certified } \\
\text { value }\end{array}$ & $\begin{array}{c}\% \\
\text { recovery }\end{array}$ & & & & \\
\hline As & $\begin{array}{c}3.07 \pm \\
0.08\end{array}$ & NA & NA & $14.4 \pm 1.2$ & NA & NA & $\begin{array}{c}2.85 \pm \\
0.12\end{array}$ & NA & NA & $\begin{array}{c}12.0 \pm \\
0.8\end{array}$ & $\begin{array}{c}32.3 \pm \\
0.6\end{array}$ & $\begin{array}{c}31.3 \pm \\
1.2\end{array}$ & 103 \\
\hline Cd & $\begin{array}{c}7.54 \pm \\
0.27\end{array}$ & $\begin{array}{l}7.34 \pm \\
0.35\end{array}$ & 103 & $\begin{array}{c}3.62 \pm \\
0.67\end{array}$ & $\begin{array}{c}3.77 \pm \\
0.28\end{array}$ & 96 & $\begin{array}{c}0.28 \pm \\
0.04\end{array}$ & $\begin{array}{c}0.27 \pm \\
0.06\end{array}$ & 103 & $\begin{array}{c}0.98 \pm \\
0.01\end{array}$ & $\begin{array}{c}12.4 \pm \\
0.3\end{array}$ & $\begin{array}{c}11.6 \pm \\
0.3\end{array}$ & 107 \\
\hline $\mathrm{Cr}$ & $\begin{array}{c}2.67 \pm \\
0.18\end{array}$ & $\begin{array}{c}2.26 \pm \\
0.16\end{array}$ & 118 & $43.4 \pm 1.2$ & $\begin{array}{c}45.7 \pm \\
2.0\end{array}$ & 95 & $145 \pm 7.8$ & $\begin{array}{c}143 \pm \\
7.0\end{array}$ & 101 & $\begin{array}{c}62.5 \pm \\
0.4\end{array}$ & $\begin{array}{c}254 \pm \\
3.2\end{array}$ & $\begin{array}{c}262 \pm \\
7.8\end{array}$ & 97 \\
\hline $\mathrm{Cu}$ & $42.1 \pm 2.7$ & $\begin{array}{c}49.3 \pm \\
1.7\end{array}$ & 85.4 & $102 \pm 3.2$ & $\begin{array}{c}124 \pm \\
3.0\end{array}$ & 82.3 & $54.0 \pm 2.2$ & $\begin{array}{c}55.2 \pm \\
3.7\end{array}$ & 97.8 & $\begin{array}{c}41.9 \pm \\
1.1\end{array}$ & $\begin{array}{c}240 \pm \\
3.1\end{array}$ & $\begin{array}{c}277 \pm \\
4.8\end{array}$ & 87 \\
\hline $\mathrm{Ni}$ & $14.9 \pm 0.9$ & $\begin{array}{c}15.4 \pm \\
0.9\end{array}$ & 96.8 & $22.5 \pm 2.4$ & $\begin{array}{c}26.6 \pm \\
1.3 \\
\end{array}$ & 84.6 & $13.2 \pm 0.6$ & $\begin{array}{c}15.3 \pm \\
0.9\end{array}$ & 86.3 & $\begin{array}{c}42.1 \pm \\
0.82\end{array}$ & $\begin{array}{c}92.7 \pm \\
4.0\end{array}$ & $\begin{array}{c}93.7 \pm \\
1.5\end{array}$ & 99 \\
\hline $\mathrm{Pb}$ & $\begin{array}{c}3.01 \pm \\
0.17\end{array}$ & $\begin{array}{c}3.18 \pm \\
0.21\end{array}$ & 94.7 & $122 \pm 4.4$ & $\begin{array}{c}126 \pm \\
3.0\end{array}$ & 96.8 & $\begin{array}{c}8.83 \pm \\
0.26\end{array}$ & $\begin{array}{c}9.28 \pm \\
1.92\end{array}$ & 95.2 & $\begin{array}{c}12.8 \pm \\
0.4\end{array}$ & $\begin{array}{c}147 \pm \\
1.3\end{array}$ & $\begin{array}{c}122 \pm \\
2.7\end{array}$ & 120 \\
\hline $\mathrm{Zn}$ & $195 \pm 9.2$ & $\begin{array}{c}205 \pm \\
6.0\end{array}$ & 95.1 & $104 \pm 1.2$ & $\begin{array}{c}114 \pm \\
5.0\end{array}$ & 91.2 & $37.1 \pm 1.7$ & $\begin{array}{c}45.7 \pm \\
3.4\end{array}$ & 81.2 & $118 \pm 3.0$ & $\begin{array}{c}454 \pm \\
3.8\end{array}$ & $\begin{array}{c}450 \pm \\
3.9\end{array}$ & 101 \\
\hline
\end{tabular}

$\mathrm{NA}=$ not available

Note: Number of replicate samples $(n=3)$ 
Table 4. Summary of XRD data for selected soil samples from Site B

\begin{tabular}{|c|c|c|c|c|}
\hline $\begin{array}{l}\text { Sample } \\
\text { name }\end{array}$ & $\begin{array}{c}\text { Total As } \\
\text { concentration } \\
(\mathrm{mg} / \mathrm{kg})\end{array}$ & $\begin{array}{c}\text { Major } \\
\text { component } \\
(>10 \%)\end{array}$ & $\begin{array}{c}\text { Minor component } \\
(>1 \%)\end{array}$ & $\begin{array}{l}\text { Trace component } \\
(<1 \%)\end{array}$ \\
\hline \#21 & \multirow[b]{2}{*}{$40-199$} & Quartz & $\begin{array}{c}\text { Albite, Microcline, } \\
\text { Muscovite }\end{array}$ & $\begin{array}{c}\text { Kaolinite, Dolomite, } \\
\text { Hematite }\end{array}$ \\
\hline \#22 & & $\begin{array}{l}\text { Quartz, } \\
\text { Calcite }\end{array}$ & NA & $\begin{array}{c}\text { Albite, Microcline, } \\
\text { Kaolinite, Ankerite, } \\
\text { Hematite }\end{array}$ \\
\hline \#18 & \multirow{2}{*}{$200-359$} & Quartz & $\begin{array}{l}\text { Albite, Microcline, } \\
\text { Muscovite, } \\
\text { Hematite }\end{array}$ & $\begin{array}{c}\text { Kaolinite, Chlorite, Calcite, } \\
\text { Ankerite }\end{array}$ \\
\hline \#19 & & Quartz & $\begin{array}{l}\text { Albite, Microcline, } \\
\text { Muscovite }\end{array}$ & $\begin{array}{c}\text { Magnesiohornblende, } \\
\text { Kaolinite, Chlorite, } \\
\text { Ankerite, Hematite }\end{array}$ \\
\hline$\# 20$ & \multirow{2}{*}{$360-519$} & Quartz & Albite, Hematite & $\begin{array}{c}\text { Microcline, Clinopyroxene, } \\
\text { Kaolinite, Calcite, } \\
\text { Ankerite }\end{array}$ \\
\hline$\# 14$ & & Quartz & $\begin{array}{c}\text { Albite, Microcline, } \\
\text { Muscovite, } \\
\text { Hematite }\end{array}$ & Kaolinite \\
\hline \#13 & \multirow{4}{*}{$>1000$} & $\begin{array}{l}\text { Quartz, } \\
\text { Calcite, } \\
\text { Hematite }\end{array}$ & Albite, Kaolinite & $\begin{array}{c}\text { Clinopyroxene, Muscovite, } \\
\text { Chlorite, Ankerite }\end{array}$ \\
\hline \#15 & & $\begin{array}{l}\text { Quartz, } \\
\text { Calcite, } \\
\text { Hematite }\end{array}$ & Mullite, Muscovite & $\begin{array}{l}\text { Albite, Microcline, } \\
\text { Ankerite, Bassanite }\end{array}$ \\
\hline \#16 & & Quartz & $\begin{array}{c}\text { Albite, } \\
\text { Clinopyroxene, } \\
\text { Muscovite, } \\
\text { Hematite }\end{array}$ & $\begin{array}{l}\text { Microcline, Kaolinite, } \\
\text { Ankerite }\end{array}$ \\
\hline$\# 17$ & & Quartz & $\begin{array}{l}\text { Albite, Calcite, } \\
\text { Hematite }\end{array}$ & $\begin{array}{c}\text { Microcline, Clinopyroxene, } \\
\text { Muscovite, Kaolinite, } \\
\text { Ankerite }\end{array}$ \\
\hline CRM 059-50 & $149 \pm 3.30$ & Quartz & $\begin{array}{c}\text { Kaolinite, } \\
\text { Hematite, Halite }\end{array}$ & $\begin{array}{c}\text { Microcline, Chlorite, } \\
\text { Calcite }\end{array}$ \\
\hline NIST 2710a & $1540 \pm 100$ & Quartz & $\begin{array}{l}\text { Albite, Microcline, } \\
\text { Muscovite, Jarosite }\end{array}$ & $\begin{array}{l}\text { Magnesiohornblende, } \\
\text { Kaolinite, Chlorite, Pyrite }\end{array}$ \\
\hline
\end{tabular}


Table 5. Summary of micro-Raman data for selected samples from Site B

\begin{tabular}{|c|c|c|c|c|}
\hline $\begin{array}{c}\text { Sample } \\
\text { name }\end{array}$ & $\begin{array}{c}\text { Total As } \\
\text { concentration } \\
(\mathbf{m g} / \mathbf{k g})\end{array}$ & Major & Minor & Trace \\
\hline$\# 13$ & $5280 \pm 63$ & Quartz & $\begin{array}{c}\text { Feldspar, Calcite, } \\
\text { Hematite, }\end{array}$ & $\begin{array}{c}\text { Pharmacosiderite, } \\
\text { Pyrrhotite, Goethite, } \\
\text { Martite, Magnetite. }\end{array}$ \\
\hline$\# 14$ & $514 \pm 10$ & Quartz & $\begin{array}{c}\text { Feldspar, } \\
\text { Hematite, Calcite. }\end{array}$ & $\begin{array}{c}\text { Rutile, Muscovite, } \\
\text { Pyrrhotite, }\end{array}$ \\
\hline$\# 15$ & $2680 \pm 42$ & Quartz & Hematite, Calcite & Goethite \\
\hline$\# 16$ & $24900 \pm 994$ & Quartz & Feldspar & $\begin{array}{c}\text { Amorphous Carbon } \\
\text { (soot), Chromite, } \\
\text { Psilomelane, Mimetite, } \\
\text { Gypsum, Goethite }\end{array}$ \\
\hline
\end{tabular}


Table 6. Summary of mineralogy, solid-phase fractionation and chemical extraction of As in urban residential soils.

\begin{tabular}{|c|c|c|c|}
\hline Technique & Information gathered & Main Findings & Comments \\
\hline CISED & $\begin{array}{c}\text { Geochemical } \\
\text { assignment of } \\
\text { extractable As phases }\end{array}$ & $\begin{array}{c}\text { Fe-Ca arsenate } \\
\text { Fe arsenate }\end{array}$ & $\begin{array}{c}\text { Identified extractable } \\
\text { As phases }\end{array}$ \\
\hline SES & $\begin{array}{c}\text { As extracted using } \\
\text { Reducible fraction }\end{array}$ & Fe-oxides & Identified As mobility \\
& $\begin{array}{c}\text { Major, Minor and Trace } \\
\text { mineral components }\end{array}$ & $\begin{array}{c}\text { Major minerals: Quartz, } \\
\text { Hematite \& Calcite }\end{array}$ & $\begin{array}{c}\text { No As components } \\
\text { identified }\end{array}$ \\
\hline Micro-RAMAN & $\begin{array}{c}\text { Major, Minor and Trace } \\
\text { mineral components }\end{array}$ & $\begin{array}{c}\text { Major: Quartz; Minor: } \\
\text { Feldspar, Hematite \& } \\
\text { Calcite: Trace: included } \\
\text { Pharmacosiderite \& } \\
\text { Mimetite }\end{array}$ & $\begin{array}{c}\text { Pharmacosiderite \& } \\
\text { Mimetite are As- } \\
\text { bearing minerals }\end{array}$ \\
\hline Individual & Individual particle & As-Pb & $\begin{array}{c}\text { Significant particle } \\
\text { density with As - } \\
\text { article SEM- }\end{array}$ \\
EDX & identification & As-Fe & \\
\hline
\end{tabular}


Figure 1. Identified number of components by different modelling techniques (a) Factor analysis (b) Average absolute differences (c) Bayesian procedure (d) Akaike information criterion for NIST 2710a

(a)

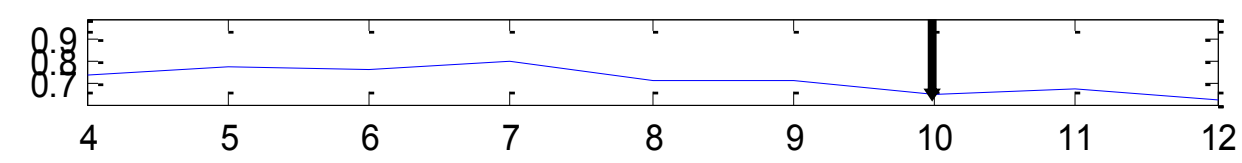

Look for Min(Average absolute diffrences)

(b)

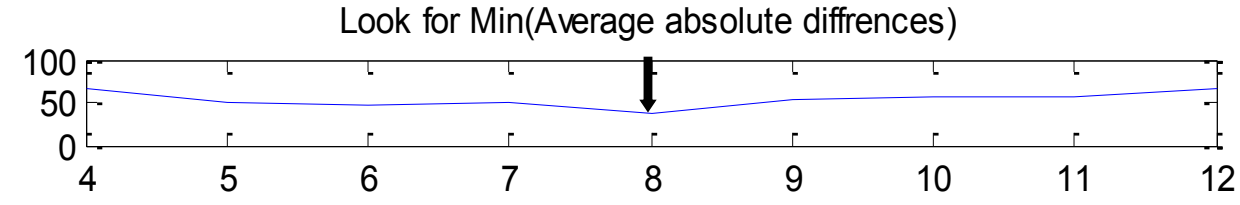

Look for Min(BIC)

(c) 3000

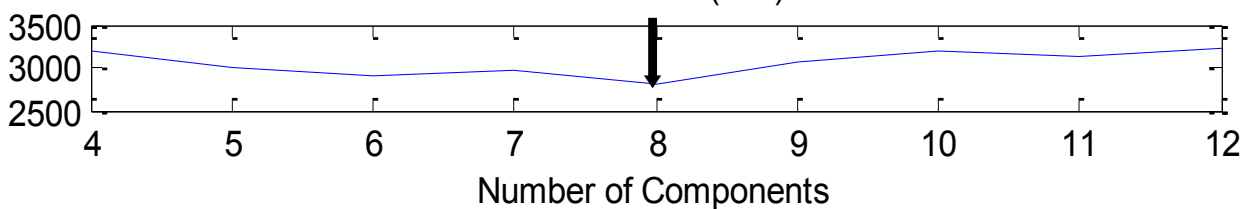

AICc Look for Min

(d)

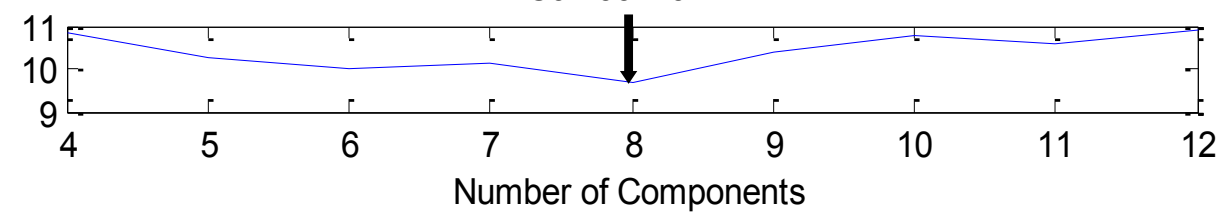


Figure 2. Identified number of components by different modelling techniques: Factor analysis, Average absolute differences, Bayesian procedure, and Akaike information criterion* for (a) Site A (Samples \#1 - \#12) (b) Site B (samples \#13 - \#22)

(a)
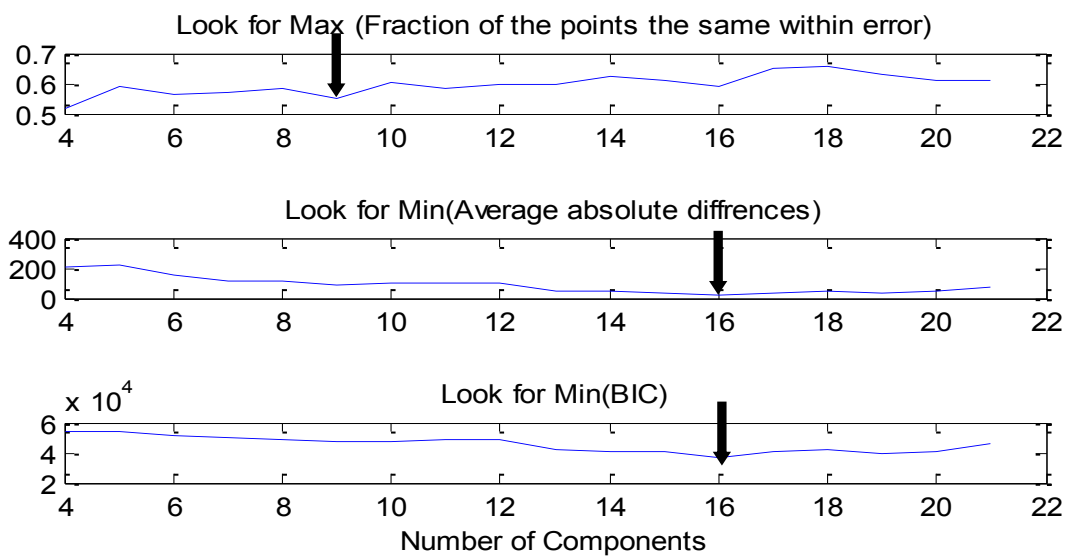

AICc Look for Min

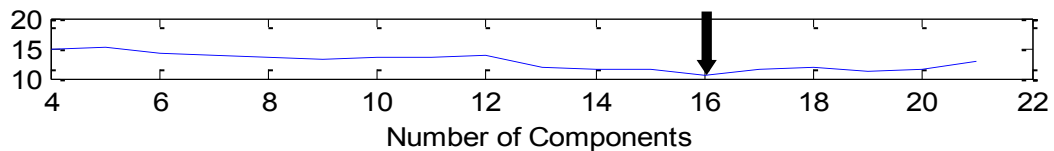

(b)
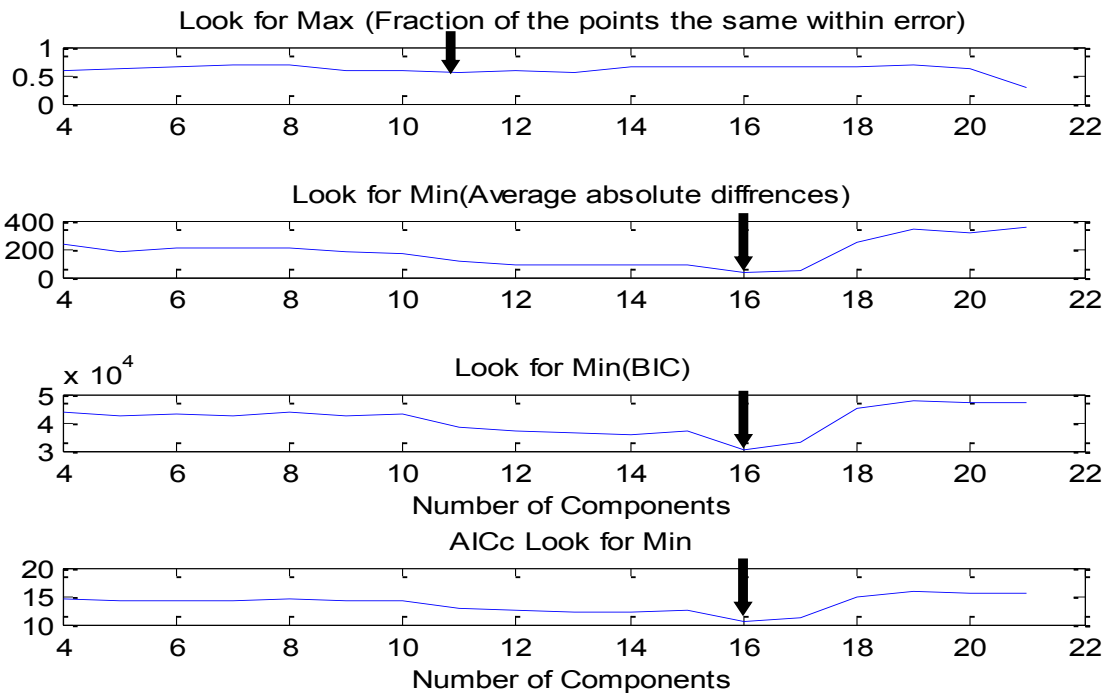

* Sequence of Factor analysis, Average absolute differences, Bayesian procedure and Akaike information criterion in Figure (a) and (b) as for Figure 1. 
Figure 3. Distribution of total As extracted between physicochemical components in (a) Site A (samples \#1 - \#12) (b) Site B (samples \#13 - \#22)

(a)

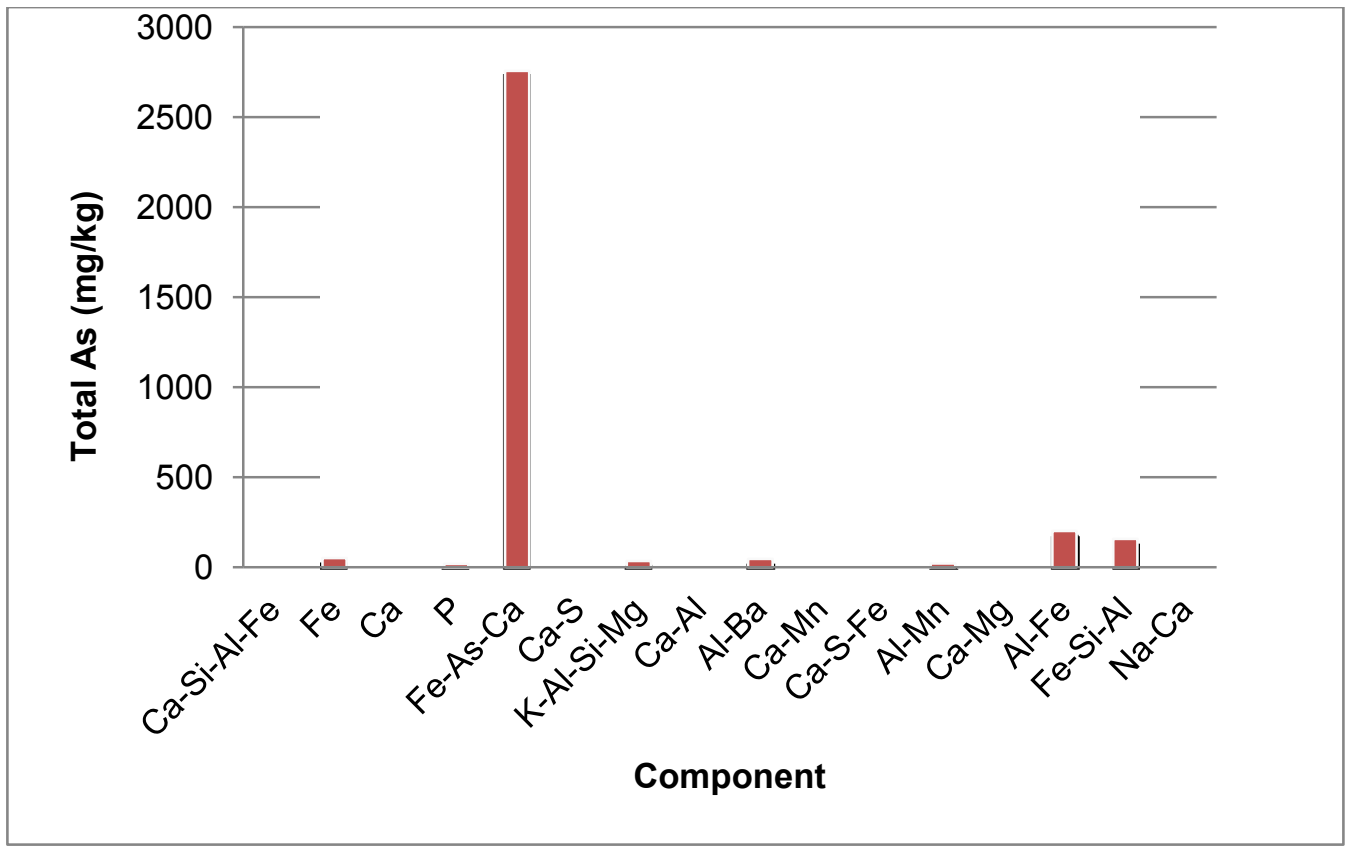

(b)

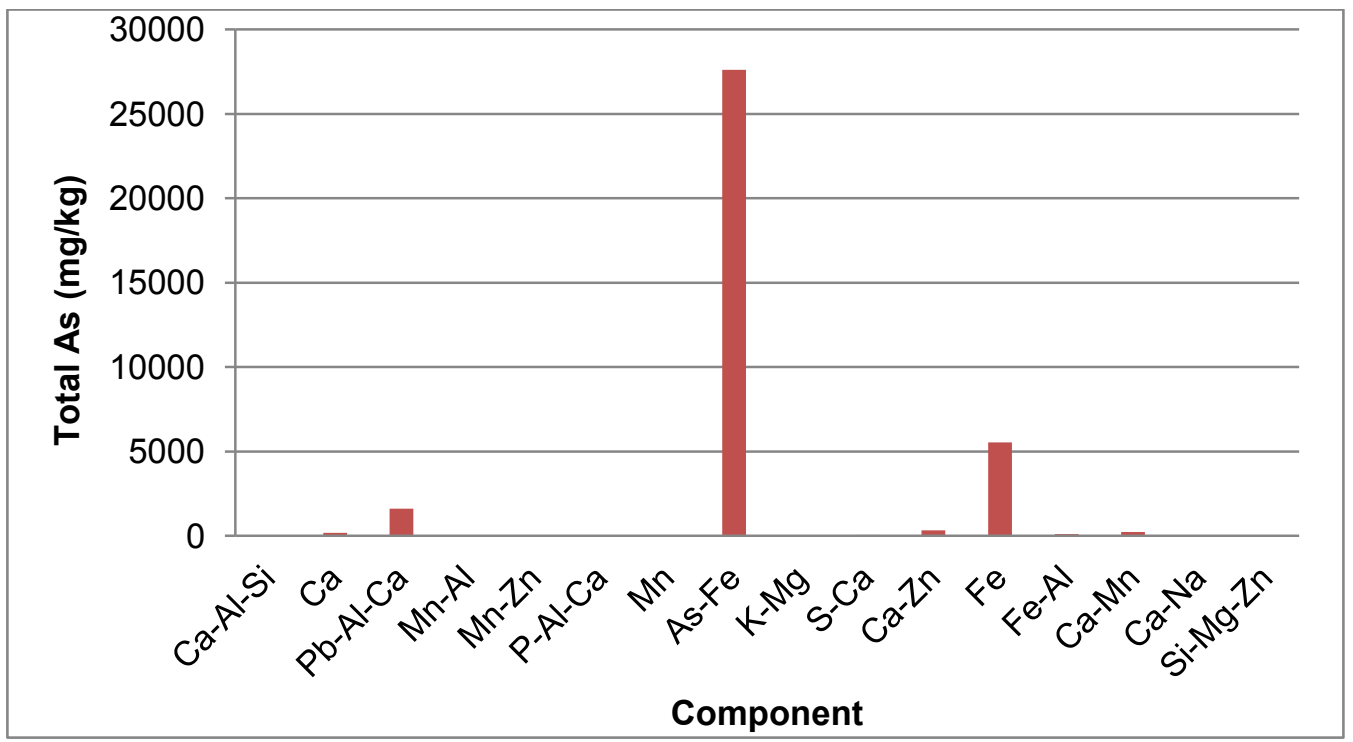


Figure 4. Component distribution plots: samples \#1 - \#12 are for Site A (Fe-As-Ca) and samples \#13 - \#22 for Site B (As-Fe profiles).

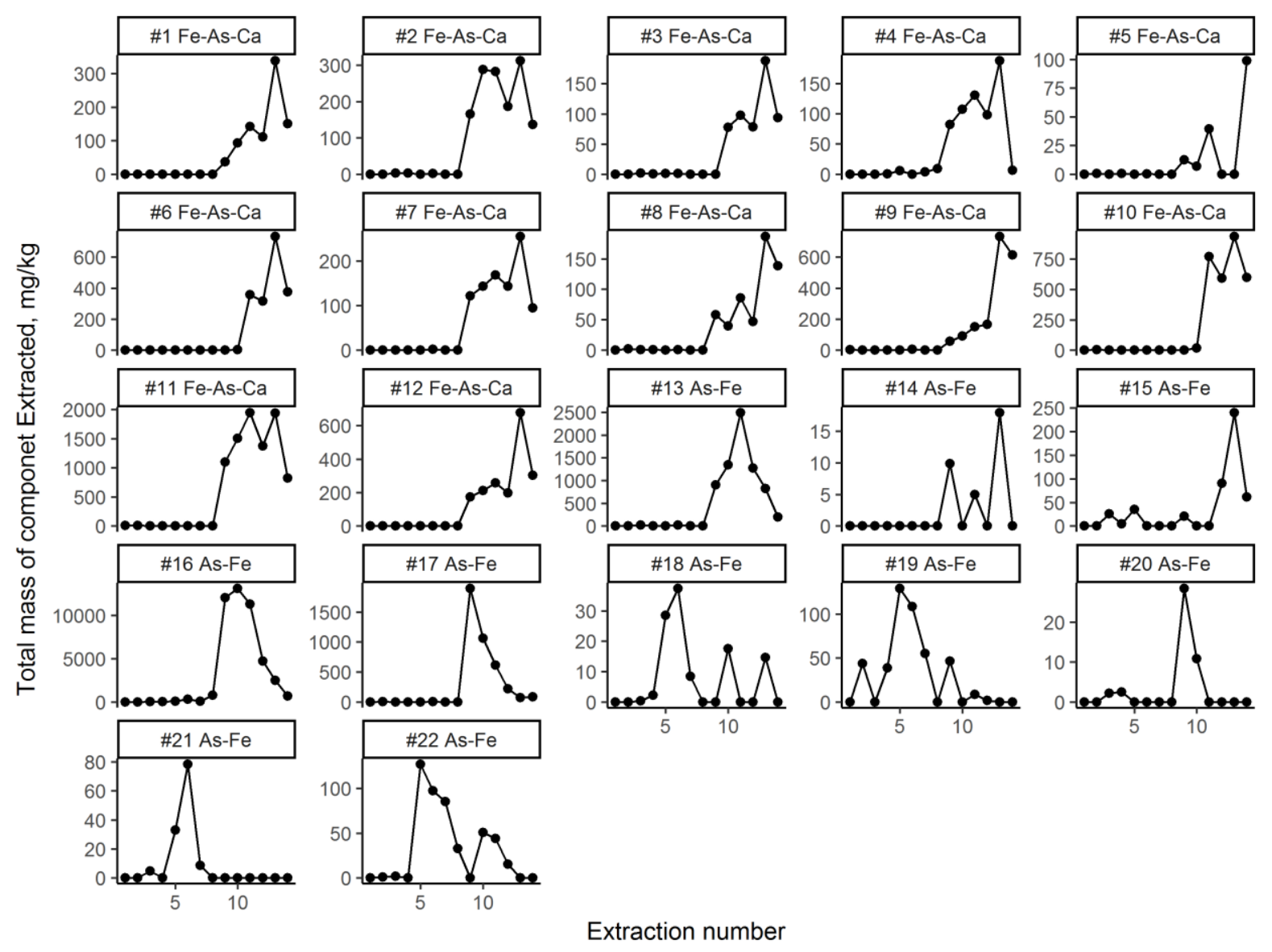


Figure 5. Arsenic Distribution using BCR-SES across both sites*

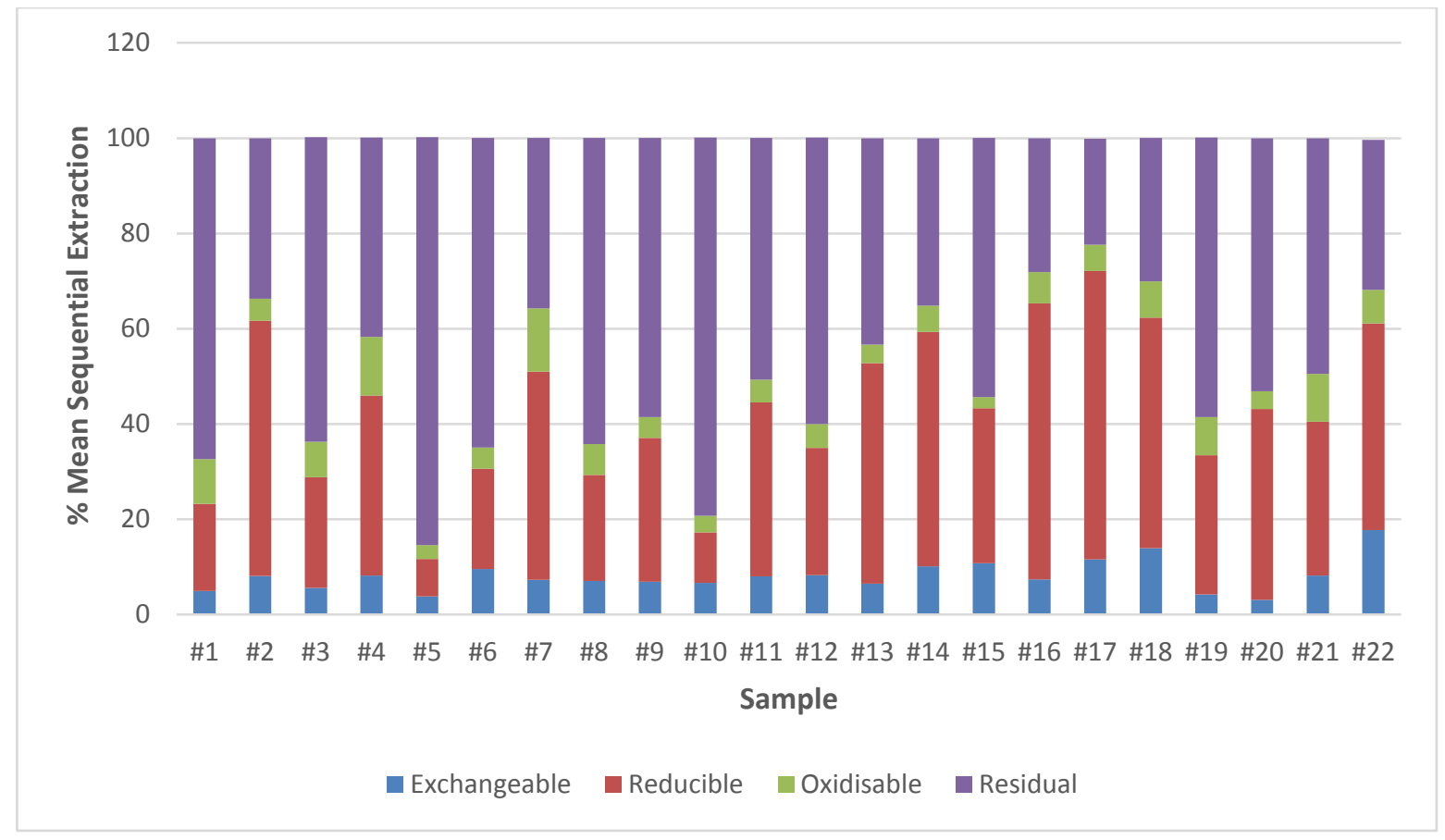

* Site A (Samples \#1 - \#12) and Site B (samples \#13 - \#22) 
Figure 6. Particle abundance (\%), as determined by SEM-EDX, of major and trace elements in selected samples*

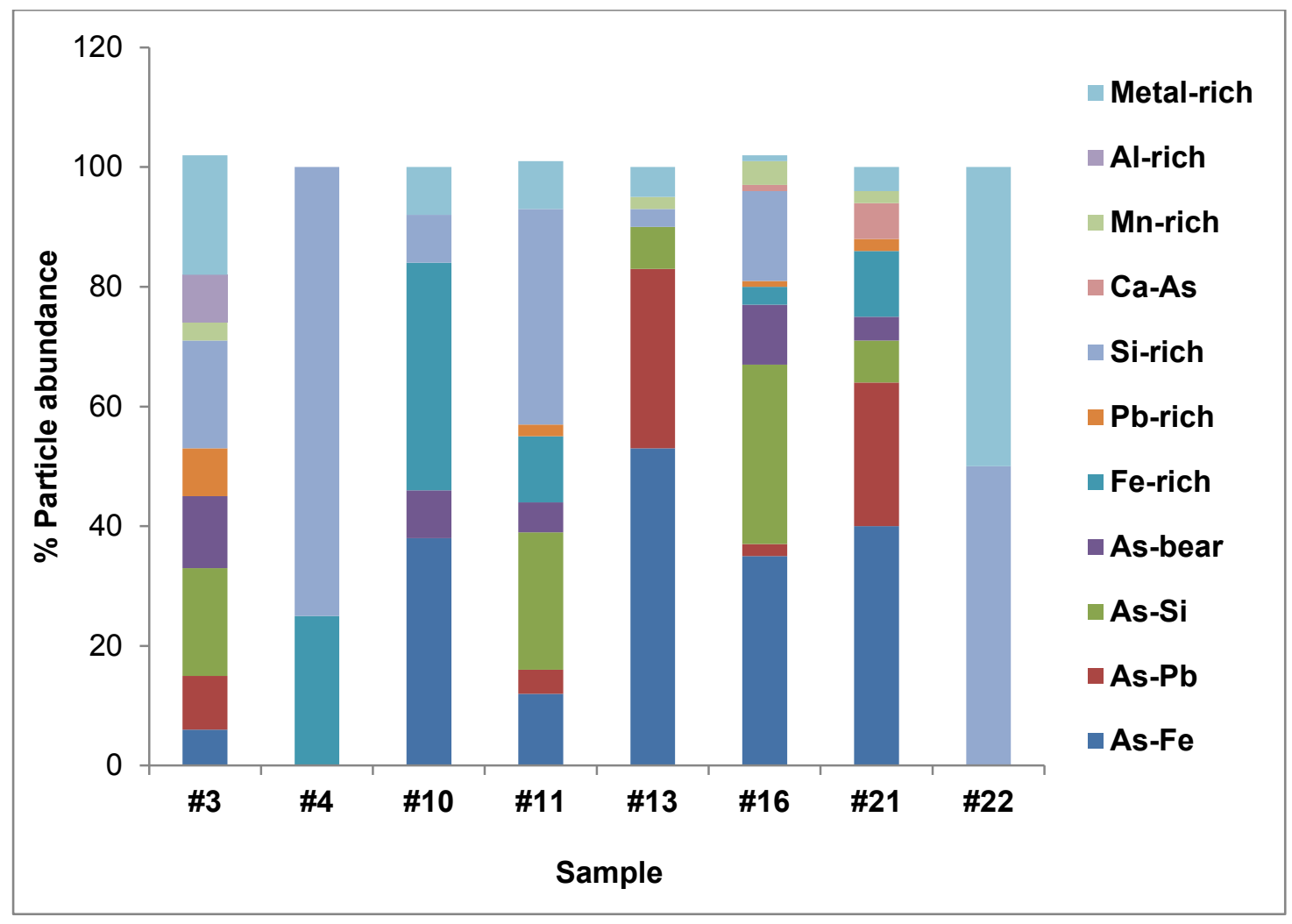

* Samples \#3 - \#11 are from Site A and Samples \#13 - \#22 are from Site B 
Figure 7. Individual particle analysis by SEM-EDX for an (a) As-Pb rich particle (sample \#13) and an (b) As-Fe rich particle (sample \#21)

(a)

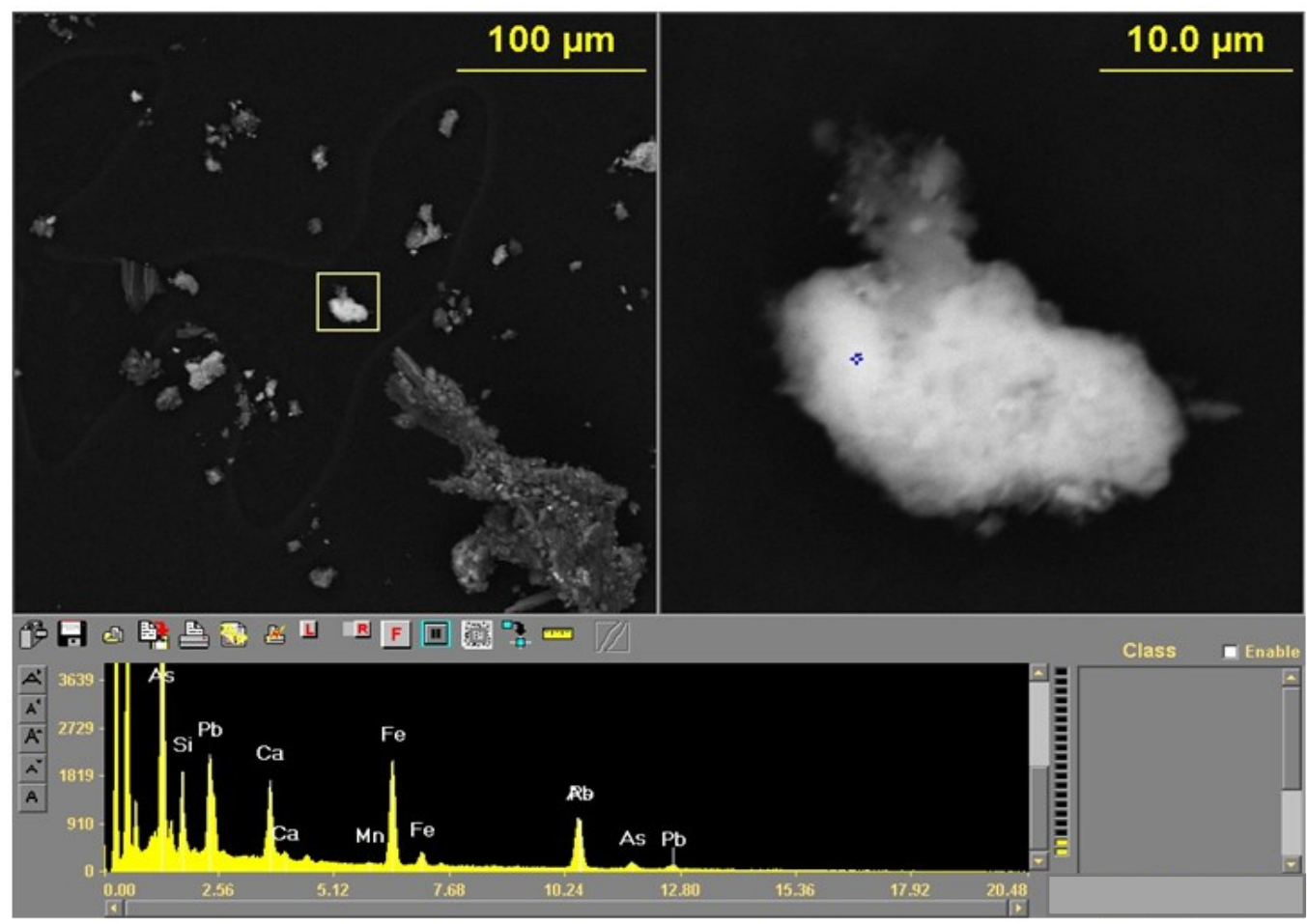

(b)

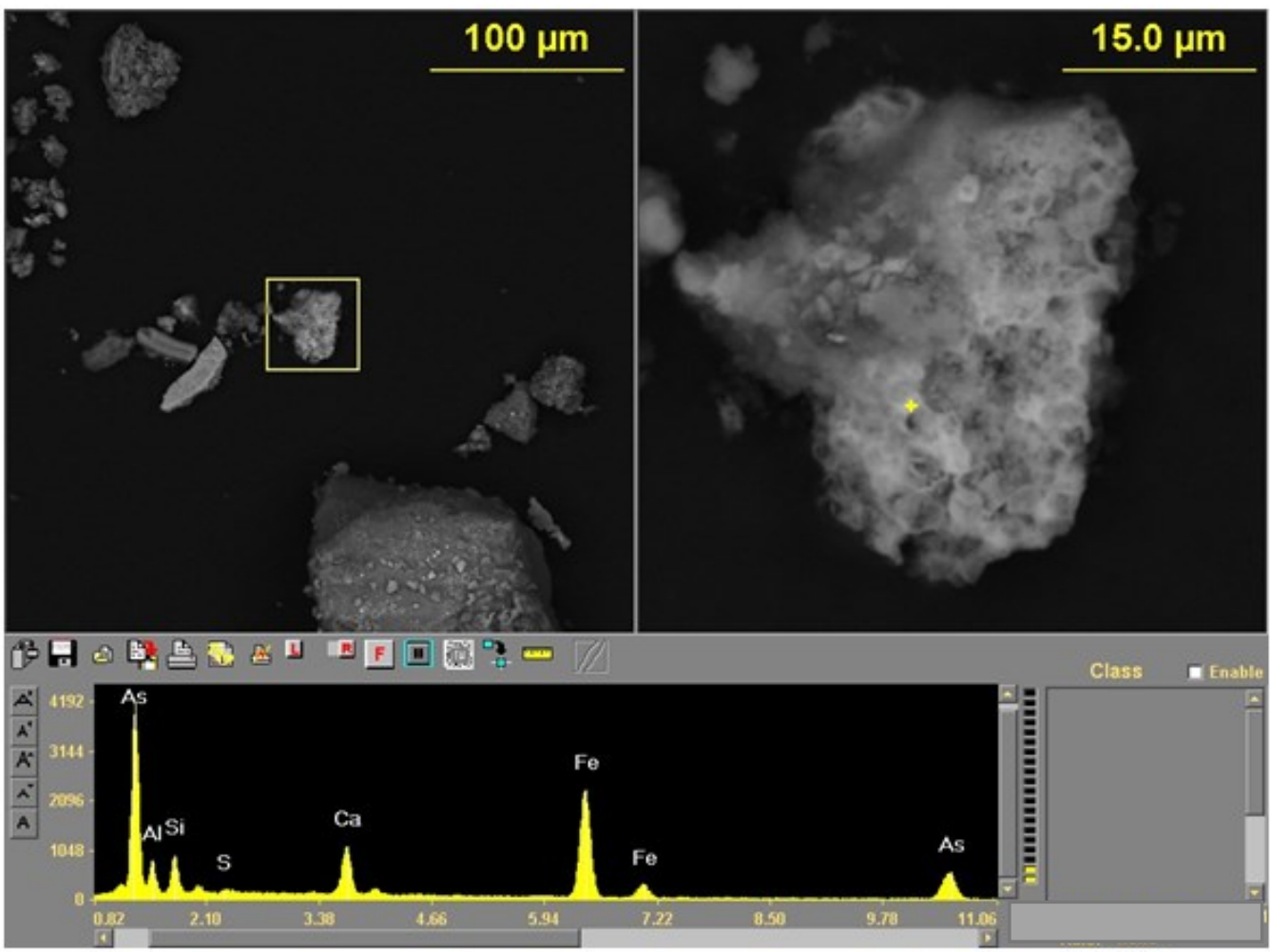

